\title{
Bradykinin-activated contractile signalling pathways in human myometrial cells are differentially regulated by arrestin proteins
}

JM Willets*, PJ Brighton, LN Windell, S Rana, CA Nash and JC Konje

Endocannabinoid Research Group, Reproductive Sciences Section, Department of Cancer Studies and Molecular Medicine, University of Leicester, Leicester Royal Infirmary, Leicester, LE2 7LX, United Kingdom

*Corresponding author: Jonathon M. Willets, Reproductive Sciences Section, Department of Cancer Studies and Molecular Medicine, University of Leicester, Clinical Sciences Building, Leicester Royal Infirmary, Leicester, LE2 7LX, U.K.

Tel: +44 116-252-5883; Fax: +44 116-252-5846; E-mail: jmw23@le.ac.uk 


\begin{abstract}
Bradykinin is associated with infections and inflammation, which given the strong correlation between uterine infection and preterm labour may imply that it could play a role in this process. Therefore, we investigated bradykinin signalling, and the roles that arrestin proteins play in their regulation in human myometrial cells. Bradykinin induced rapid, transient intracellular $\mathrm{Ca}^{2+}$ increases that were inhibited following $\mathrm{B}_{2}$ receptor $\left(\mathrm{B}_{2} \mathrm{R}\right)$ antagonism. Arrestin 2 or arrestin 3 depletion enhanced and prolonged bradykinin-stimulated $\mathrm{Ca}^{2+}$ responses, and attenuated $\mathrm{B}_{2} \mathrm{R}$ desensitization. Knockdown of either arrestin enhanced $\mathrm{B}_{2} \mathrm{R}-$ stimulated ERK1/2 signals. Moreover, depletion of either arrestin elevated peak-phase p38MAPK signalling, yet only arrestin3 depletion prolonged $\mathrm{B}_{2} \mathrm{R}$-induced p38-MAPK signals. Arrestin2-knockdown augmented bradykinin-induced cell movement. Bradykinin stimulates pro-contractile signalling mechanisms in human myometrial cells and arrestin proteins play key roles in their regulation. Our data suggest bradykinin not only acts as an utertonin, but may have the potential to enhance the contractile environment of the uterus.
\end{abstract}




\section{Graphical abstract}

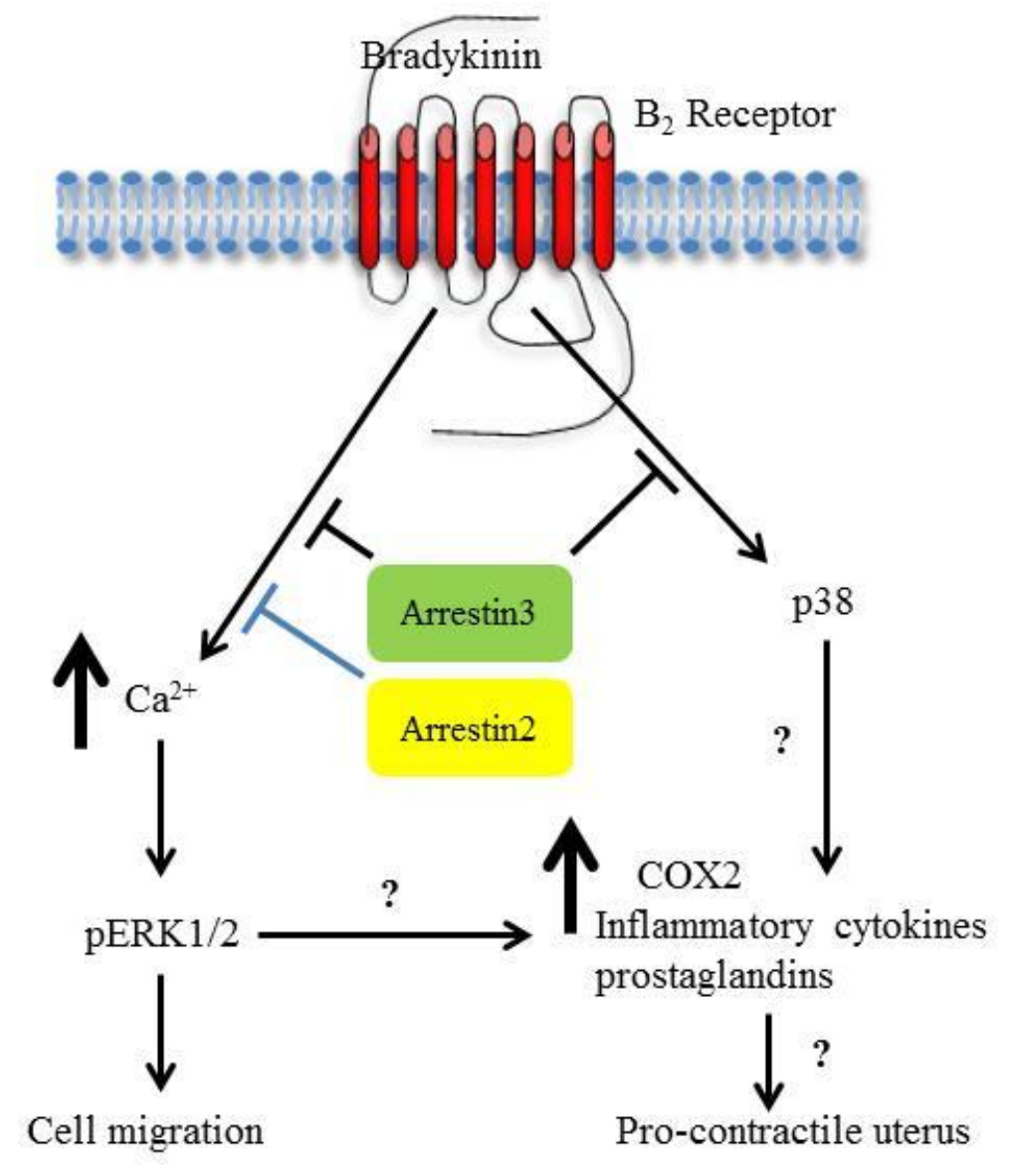

Bradykinin-stimulates pro-contractile signalling pathways in human myometrial smooth muscle cells which induces cellular movement. The bradykinin-activated signalling pathways regulated by arrestin proteins are shown alongside potential pathways by which bradykinin may induce a pro-contractile phenotype through MAPK signalling are displayed as '?'. 


\title{
Highlights
}

Bradykinin activates $\mathrm{Ca}^{2+}$ signals via bradykinin $\mathrm{B}_{2}$ receptors in myometrial cells.

Arrestin2/3 depletion attenuates bradykinin $\mathrm{B}_{2}$ receptor desensitization.

Arrestin2/3 depletion enhanced bradykinin $\mathrm{B}_{2}$ receptor ERK1/2 signalling.

Arrestin3 depletion increased and prolonged bradykinin-stimulated p38 MAPK signals.

Bradykinin activates pro-contractile signalling pathways in the human myometrium.

Key words: Bradykinin, myometrium, arrestin, migration, myometrial contraction, $\mathrm{B}_{2}$ receptor, MAPK

\begin{abstract}
Abbreviations: $B_{2} R$, bradykinin $B_{2}$ receptor; $\left[\mathrm{Ca}^{2+}\right]_{i}$, intracellular calcium concentration; ERK, extracellular signal-regulated kinase; GPCR, G protein-coupled receptor; GRK, G protein-coupled receptor kinase; eGFP-PH, e-GFP-tagged pleckstrin homology domain of phospholipase $\mathrm{C} \delta$; pERK, threonine- and tyrosine-phosphorylated extracellular signalregulated kinase; MAPK, mitogen-activated protein kinase
\end{abstract}




\section{Introduction}

Bradykinin is a member of the kinin family, potent pro-inflammatory peptides which are stored as precursor peptides in the plasma membranes of cells (Blaes et al., 2013). Kinins are liberated into the circulation following cleavage by serine proteases called kallikreins, a process that is greatly enhanced during bacterial infections (Blaes et al., 2013). Interestingly, the presence of the kallikein-kinin system in the human endometrium and myometrium (Clements et al., 1994), suggests that the uterus has the capacity to produce pro-inflammatory agents such as bradykinin in response to bacterial infections. Moreover, as there is a strong correlation between infection and preterm labour (Goldenberg et al., 2008), and that bradykinin is known to induce myometrial contraction (Senior et al., 1976; Janicek et al., 2007), it is possible that bradykinin signalling may play a part in the induction of myometrial contraction not only secondary to infectious stimuli, but also conceivably in the normal parturition process. Indeed, in rats it has been suggested that the actions of bradykinin are mediated through the bradykinin $\mathrm{B}_{2}$ receptor $\left(\mathrm{B}_{2} \mathrm{R}\right)$ (Murone et al., 1999), which recruits $\mathrm{G} \alpha_{\mathrm{q}}$ and/or $\mathrm{G} \alpha_{\mathrm{i}}$ to activate phospholipase C (PLC) and inhibit adenylyl, increasing intracellular $\left(\left[\mathrm{Ca}^{2+}\right]_{\mathrm{i}}\right)$ and reducing cyclic AMP concentrations, respectively (Marceau et al., 1998; Yusuf et al., 2000). Furthermore, $\mathrm{B}_{2} \mathrm{R}$ receptor activation can induce MAPK signalling (Fleming et al., 1995; Blaukat et al., 1999), and activate phospholipase $\mathrm{A}_{2}$, liberating arachidonic acid and subsequently increasing prostaglandin synthesis (Leeb-Lundberg et al., 2005). Activation of any or all of these signalling pathways may explain why bradykinin induces uterine contractions (Wassdal et al., 1998; Trzeciak et al., 2000).

The majority of bradykinin actions are mediated through two $\mathrm{G}$ protein-coupled receptors (GPCR) termed $\mathrm{B}_{1}$ and $\mathrm{B}_{2}$, which have little sequence homology (e.g. $36 \%$ for human 
bradykinin receptors). In general $B_{2}$ receptors $\left(B_{2} R\right)$ are constitutively expressed in most tissues including smooth muscle (Couture et al., 2001), whereas, although $\mathrm{B}_{1}$ expression is negligible in healthy cells its' expression is inducible, being dramatically enhanced as a result of tissue injury, infection, inflammation or anoxia (Marceau et al., 1998)..

Despite activating many of the same signalling pathways, the kinetics of $\mathrm{B}_{1}$ and $\mathrm{B}_{2}$ receptor signalling are very different. $\mathrm{B}_{2} \mathrm{R}$ activation is typically transient, desensitizing rapidly (Faussner et al., 1998), whilst $\mathrm{B}_{1}$ receptor signalling is prolonged due to its relative insensitivity to phosphorylation and desensitization (Blaukat et al., 1999). GPCR desensitization is typically mediated through the action of $\mathrm{G}$ protein-coupled receptor kinases (GRK), which phosphorylate agonist-occupied receptors at serine and/or threonine moieties (Willets et al., 2003). GRK phosphorylation promotes the recruitment of arrestin proteins, whose binding physically blocks interaction of GPCR and G proteins, prior to promoting receptor internalisation (Lamb et al., 2001; Willets et al., 2003; DeWire et al., 2007). Indeed, data from model cell systems indicate that $\mathrm{B}_{2} \mathrm{R}$ are substrates for several GRKs (Blaukat et al., 2001). As GRK mediated phosphorylation promotes arrestin interaction, it is also not surprising that arrestin proteins are reported to regulate exogenously expressed $\mathrm{B}_{2} \mathrm{R}$ signalling in HEK293 cells (Zimmerman et al., 2011). Previous data from rats highlight the presence of $\mathrm{B}_{2} \mathrm{R}$ on myometrial cells (Murone et al., 1999), activation of which would explain why bradykinin induces uterine contractions (Wassdal et al., 1998; Trzeciak et al., 2000). Notwithstanding these findings, presently little is known regarding the consequences of and regulatory mechanisms involved in bradykinin receptor signalling in the myometrium. Here we show that bradykinin activates pro-contractile signalling pathways within the human myometrium, and characterise the molecular mechanisms underlying bradykinin receptor regulation. 


\section{Materials and methods}

\subsection{Cell culture}

The immortalised human ULTR myometrial cell line (Perez-Reyes et al., 1992) was cultured in Dulbecco's minimal essential medium, supplemented with $10 \%$ foetal calf serum, penicillin $\left(100 \mathrm{IUml}^{-1}\right)$, streptomycin $\left(100 \mu \mathrm{gml}^{-1}\right)$, and amphotericin $\mathrm{B}\left(2.5 \mu \mathrm{gml}^{-1}\right)$ and Glutamax-1. Cells were maintained under humidified conditions at $37^{\circ} \mathrm{C}$, in air $/ 5 \% \mathrm{CO}_{2}$.

\section{2. siRNA targeted arrestin and GRK depletion}

Endogenous arrestin 2 or arrestin 3 were targeted for depletion using the following previously characterised (Brighton et al., 2011a; Brighton et al., 2011b) siRNA constructs designed to target either human arrestin2 (ARRB1) (5'-GGAGAUCUAUUACCAUGGtt-3') or arrestin3 (ARRB2) siRNA (5'-CGAACAAGAUGACCAGGUAtt-3') (Ambion, Applied Biosystems, Warrington, UK). For MAPK and single cell imaging experiments ULTR cells $(150,000$ per well) were transfected with either negative control (non-targeting $100 \mathrm{nM}$ ), anti-arrestin2 $(100 \mathrm{nM})$, or anti-arrestin3 $(10 \mathrm{nM})$ siRNA constructs using the Interferin ${ }^{\mathrm{TM}}$ transfection reagent (Polyplus, NY, USA), as per manufacturers' instructions. Endogenous GRK proteins were targeted for depletion using the following previously characterised (Willets et al., 2009) siRNA constructs designed to target either GRK2 (5-GGCAGCCAGUGACCAAAAAtt-3), GRK3 (Ambion, Applied Biosystems, Warrington, UK) using the Interferin transfection reagent according to the manufacturer's instructions. 


\subsection{Assessment of agonist-stimulated $\mathrm{Ca}^{2+}$ signalling}

To assess bradykinin mediated $\left[\mathrm{Ca}^{2+}\right]_{\mathrm{i}}$ changes, ULTR cells were seeded into 96 -well plates. When $90 \%$ confluent, cells were washed with Krebs buffer (composition (mM); HEPES 10, $\mathrm{NaHCO}_{3}$ 1.3, D-Glucose 11.7, $\mathrm{MgSO}_{4}$ 1.2, $\mathrm{KH}_{2} \mathrm{PO}_{4}$ 1.2, $\mathrm{KCl}$ 4.7, $\mathrm{NaCl} 118$ and $\mathrm{CaCl}_{2}$ 1.3, $\mathrm{pH}$ 7.4) and loaded with $3 \mu \mathrm{M}$ fluo4-AM (room temperature, $1 \mathrm{~h}$ ). Cell monolayers were washed again with Krebs buffer prior to challenge with increasing concentrations of bradykinin for various time periods. Agonist-stimulated fluorescence intensity changes were measured using a NovoStar imaging system (BMG Labtech, Aylesbury, UK), and plotted graphically as percentage increase over the fluorescence at time zero. To assess whether arrestin depletion affected bradykinin-stimulated $\mathrm{Ca}^{2+}$ signalling, ULTR cells were seeded 24 $\mathrm{h}$ before transfection at a density of 10,000 cells per well and transfected with either negative control $(100 \mathrm{nM})$, anti-human arrestin2 $(100 \mathrm{nM})$ or anti-human arrestin3 (10 nM) siRNAs. Transfection was achieved using Interferin ${ }^{\mathrm{TM}}$ transfection reagent (Polyplus, NY, USA), as per manufacturers' instructions.

\subsection{Determination of bradykinin-stimulated calcium signalling and receptor desensitization in single cells}

ULTR cells were seeded onto $25 \mathrm{~mm}$ glass coverslips and when at approximately $70 \%$ confluency, loaded with the calcium sensitive dye Fluo4-AM $(3 \mu \mathrm{M})$ for $30 \mathrm{~min}$ at room temperature. Cells were maintained at $37^{\circ} \mathrm{C}$ using a temperature controller and microincubator (PDMI-2 and TC202A; Burleigh, Digitimer, Cambridge, UK), and perfused with Krebs-Henseleit buffer (composition: $\mathrm{NaCl} 134 \mathrm{mM}, \mathrm{KCl} 6 \mathrm{mM}, \mathrm{MgCl}_{2} 1 \mathrm{mM}$, glucose $10 \mathrm{mM}$, HEPES $10 \mathrm{mM}$, and $\mathrm{CaCl}_{2} 1.3 \mathrm{mM}, \mathrm{pH} \mathrm{7.4)}$ at $5 \mathrm{ml} \mathrm{min}^{-1}$. Images were captured using a Nikon (Surrey, UK) Eclipse C1Si confocal microscope, with an oil immersion 60x objective. $\left[\mathrm{Ca}^{2+}\right]_{\mathrm{i}}$ levels were determined by increases in cytosolic fluorescence in a defined 
area of interest exactly as described previously (Willets et al., 2005; Willets et al., 2008). Bradykinin $\mathrm{B}_{2} \mathrm{R}$ desensitization was determined using techniques similar to our previously validated protocols (Willets et al., 2009; Brighton et al., 2011b). Briefly, to assess receptor desensitization cells were stimulated with a maximal agonist concentration (bradykinin 1 $\mu \mathrm{M}$ ) for $30 \mathrm{sec}$ (termed $\mathrm{R} 1$ ), followed by a $5 \mathrm{~min}$ wash period before a second $30 \mathrm{sec}$ agonist challenge (100 nM, termed R2). Peak $\left[\mathrm{Ca}^{2+}\right]_{\mathrm{i}} \mathrm{R} 2$ responses were significantly attenuated compared to $\mathrm{R} 1$ and the resulting reduction in the $\mathrm{R} 2 / \mathrm{R} 1$ ratio is interpreted as an indication of receptor desensitization (Willets et al., 2009). To determine whether arrestin proteins affected receptor desensitization, cells were transfected with either negative control (100 $\mathrm{nM})$, arrestin2 $(100 \mathrm{nM})$ or arrestin3 $(10 \mathrm{nM})$ siRNAs for $48 \mathrm{~h}$ prior to experimentation as described above.

\subsection{Detection of MAPK activation}

Agonist-driven ERK1/2 activity was detected using Western blotting techniques as described previously (Brighton et al., 2009). Agonist-stimulated p38 MAPK phosphorylation was also detected through a similar Western blotting approach (Brighton et al., 2011a). Briefly, ULTR cells were seeded into 6-well plates and grown to confluency. Cells were then serum-starved for $24 \mathrm{~h}$ prior to agonist addition. Signalling was terminated with the addition of lysis buffer (composition; 20 mM Tris-HCl (pH 7.4), 1\% (v:v) Triton X-100, 2 mM EDTA, 25 mM $\beta$ glycerophosphate, $1 \mathrm{mM}$ sodium orthovanidate, $500 \mu \mathrm{M}$ phenylmethanesulfonylfluoride, 0.1

$\mathrm{mgml}^{-1}$ leupeptin, $0.2 \mathrm{mgml}^{-1}$ benzamidine, and $0.1 \mathrm{mgml}^{-1}$ pepstatin). Next, samples were centrifuged to clear insoluble material and an equal volume of $2 x$ sample buffer (composition; $250 \mathrm{mM}$ Tris-HCl, pH 6.8, 0.01\% (w:v) bromophenol blue, 2\% (w:v) sodium dodecyl sulphate, $40 \%$ (v:v) glycerol and $50 \mathrm{mM}$ ditiothreitol) and added before heating (5 min, $100^{\circ} \mathrm{C}$ ) and gel loading. Samples were separated by SDS-PAGE and transferred to nitrocellulose using Western blotting techniques. Phospho-ERK1/2 was detected using a 
specific pERK1/2 antibody (Promega, Southampton, UK), which detects the dual phosphorylated P-loop pTEpY motif of ERK1/2; phospho-p38 MAPK (pTGpY) was detected using a specific pp38 antibody (Cell Signaling, Madison, WI, USA) followed by enhanced chemiluminescence detection as per manufacturers' instruction, and exposure to autoradiography film. Densitometric analysis of the resultant autoradiographs was undertaken using the GeneGnome image analysis system and software (Syngene, Cambridge, UK). To ensure that all samples contained the same levels of protein, total ERK and p38 levels were determined by running additional gels in parallel with the detection of pERK and phosphop38. For ERK1/2 samples, uniform protein loading was confirmed by detection of totalERK1/2 proteins using an anti-total ERK1/2 antibody (Santa Cruz, CA, USA) and for p38 samples, an antibody against total p38 (Cell Signaling, Madison, WI, USA). Immunoreactive bands were visualized and quantified as described above. pERK1/2 or phospho-p38 MAPK

absorbance levels for each treatment were corrected for differences in total ERK1/2 immunoreactivity before being expressed as a percentage of the basal pERK1/2 immunoreactivity.

\subsection{Cell migration studies}

To assess the ability of bradykinin to stimulate ULTR cell motility a scratch assay was employed. Briefly, cells were seeded into 24 well plates (100,000 per well) and left for $24 \mathrm{~h}$. Cells were then serum starved for a further $24 \mathrm{~h}$ prior to scratching with a p-10 pipette tip. Once scratched the cell monolayers were washed with phosphate buffered saline to remove cell debris before fresh serum free media was added. Each scratch was visualised using a Nikon (Surrey, UK) Eclipse TE2000U microscope (4x objective) and three random views photographed. Next, cells were treated with either bradykinin $(1 \mu \mathrm{M})$ or $10 \%$ foetal calf serum and after 6,12 and $24 \mathrm{~h}$ the scratches were again photographed as described above. 
Scratch widths were measured and calibrated against a graticule to determine actual distances travelled. Data are expressed as the distance that cells migrated during the time period or scratch closure in $\mu \mathrm{m}$. For siRNA knockout experiments cells were seeded at 50,000 per well and transfected with the appropriate siRNAs as described above the next day. After a further $24 \mathrm{~h}$ cells were starved for $24 \mathrm{~h}$ prior to experimentation.

\subsection{Data analysis}

All concentration-response curves were generated and $\mathrm{EC}_{50}$ values determined using nonlinear regression analysis software Prism, version 5.0 (GraphPad Software Inc., San Diego, CA, USA). Data were analyzed using One-way or Two-way ANOVA, followed by appropriate post-hoc testing (Excel 5.0, Microsoft, Redmond, WA). Significance was accepted when $p<0.05$.

\section{Results}

\subsection{Bradykinin mediated increases in $\left[\mathrm{Ca}^{2+}\right]_{i}$}

Stimulation of ULTR cells with bradykinin resulted in a typically rapid, yet transient increase in $\left[\mathrm{Ca}^{2+}\right]_{\mathrm{i}}$ (Figure $1 \mathrm{~A}, \mathrm{C}$ ). Changes in $\left[\mathrm{Ca}^{2+}\right]_{\mathrm{i}}$ were concentration-dependent and analysis revealed $\mathrm{EC}_{50}$ value of $3.3 \mathrm{nM}$ (Figure 1B). Bradykinin-stimulated changes in $\left[\mathrm{Ca}^{2+}\right]_{\mathrm{i}}$ were virtually absent following pre-incubation with the specific bradykinin $B_{2} R$ antagonist HOE140, but were unaffected by the $\mathrm{B}_{1}$ receptor antagonist R715 (1 $\mu \mathrm{M}$; Figure $\left.1 \mathrm{C}, \mathrm{D}\right)$, suggesting that in ULTR cells bradykinin responses are mediated through the $\mathrm{B}_{2} \mathrm{R}$. 


\subsection{Characterisation of $B_{2} R$ desensitization and re-sensitization of PLC signalling}

The time course of $\mathrm{B}_{2} \mathrm{R}$ desensitization and re-sensitization were examined at the level of PLC activity by using the $\mathrm{Ca}^{2+}$-sensitive dye Fluo4. Initial experiments showed $\mathrm{B}_{2} \mathrm{R}$ stimulated increases in $\left[\mathrm{Ca}^{2+}\right]_{\mathrm{i}}$ diminished rapidly within $5 \mathrm{~min}$, even in the continued presence of bradykinin ( $1 \mu \mathrm{M}$; Figure $2 \mathrm{~A})$. Therefore, to assess receptor desensitization, cells were stimulated with a maximal bradykinin concentration $(1 \mu \mathrm{M})$ for $30 \mathrm{sec}$ (termed $\mathrm{R} 1)$, followed by a wash period $(5,10$ or $15 \mathrm{~min})$ and then a second bradykinin challenge $(1 \mu \mathrm{M}$, $30 \mathrm{sec}$, termed R2). A single (R1) pulse of bradykinin induced a transient increase in $\left[\mathrm{Ca}^{2+}\right]_{\mathrm{i}}$ which returned to baseline within 5 min (Figure 2B). When a second pulse of bradykinin was added 5 min after the first, substantially lower increases in $\left[\mathrm{Ca}^{2+}\right]_{i}$ were observed (Figure $2 \mathrm{~B}$ ). Reductions in the peak R2/R1 ratio are indicative of receptor desensitization (Willets et al., 2009; Morris et al., 2010). Increasing the washout period between bradykinin additions revealed a time-dependent recovery of bradykinin induced $\left[\mathrm{Ca}^{2+}\right]_{\mathrm{i}}$ signals, which were essentially complete (i.e. R1=R2) after 15 min (Figure 2C,D).

\subsection{Effects of arrestin depletion on $B_{2} R$ desensitization}

To assess whether arrestin depletion affected $\mathrm{B}_{2} \mathrm{R}$-stimulated $\left[\mathrm{Ca}^{2+}\right]_{\mathrm{i}}$ signals and receptor desensitization, ULTR cells were transfected with either negative-control (100 nM), antiarrestin2 $(100 \mathrm{nM})$, anti-arrestin3 $(10 \mathrm{nM})$ or both anti-arrestin2 and anti-arrestin3 siRNAs. In agreement with our previous findings (Brighton et al., 2011a), siRNA-mediated arrestin knockdown produced $>70 \%$ knockdown of targeted isoforms (Supplementary Figure 1). Initially, agonist-stimulated changes in $\left[\mathrm{Ca}^{2+}\right]_{\mathrm{i}}$ were monitored $48 \mathrm{~h}$ after transfection after addition of a single maximal bradykinin concentration $(1 \mu \mathrm{M})$. Transfection with negativecontrol siRNA had no effects on basal fluorescence $\left(\left[\mathrm{Ca}^{2+}\right]_{i}\right)$ values (Figure 3 ), or the magnitude or peak-plateau profiles of bradykinin-stimulated $\left[\mathrm{Ca}^{2+}\right]_{\mathrm{i}}$ signals (data not shown). 
Interestingly, knockdown of either arestin 2 or arrestin 3 or a combination of both increased peak $\left[\mathrm{Ca}^{2+}\right]_{\mathrm{i}}$ changes (Figure 3A). However, the plateau phase was only significantly enhanced ( $\mathrm{p}<0.01$ Two-way ANOVA; Bonferroni's post-hoc test; and confirmed following area under the curve (AUC) analysis (data mean AUC \pm SEM n=4; NC $1940 \pm 422$ vs AR3 siRNA $3012 \pm 418 ; \mathrm{p}<0.01$ one-way ANOVA; Dunnett's post-hoc test) in the absence of arrestin3 (Figure $3 \mathrm{~A}$ ). $\mathrm{B}_{2} \mathrm{R}$ desensitization was assessed using the protocol outlined above, and reassuringly after transfection with negative control siRNA, R2 ratios were reduced to a comparable level to that observed in non-transfected cells (Figure 3B,D). Following suppression of arrestin2 or arrestin3 R2 levels were markedly higher than those observed in negative control siRNA treated cells, which suggests that both arrestins play a role in the desensitization of $\mathrm{B}_{2} \mathrm{R}\left[\mathrm{Ca}^{2+}\right]_{i}$ signals. Simultaneous knockdown of both arrestins failed to prevent $\mathrm{B}_{2} \mathrm{R}$ desensitization any further than with single arrestin protein knockdown (data not shown).

\subsection{Effects of GRK depletion on $B_{2} R$ desensitization}

To assess whether depletion of individual GRK isoforms affected $B_{2} R$ desensitization we utilised our standard desensitization protocol (outlined above) to measure changes in bradykinin-stimulated $\left[\mathrm{Ca}^{2+}\right]_{\mathrm{i}}$ signals following transfection with either negative-control (100 nM), anti-GRK2 (10 nM), anti-GRK3 (100 nM), anti-GRK5 (100 nM) or anti-GRK6 (10 nM) siRNAs. In agreement, with our previous findings (Willets et al., 2009) siRNA treatment produced specific knockdown of targeted isoforms by $>70 \%$ (Supplementary Figure 1). After knockdown of GRK2 or GRK3 R2 levels of bradykinin-stimulated $\left[\mathrm{Ca}^{2+}\right]_{i}$ were markedly greater than those observed in negative-control transfected cells (Figure 3C,D), which is indicative of deceased $\mathrm{B}_{2} \mathrm{R}$ desensitization. In contrast, suppression of GRK5 or GRK6 expression failed to alter the R2/R1 ratio (Figure 3D), implying that their absence did not 
affect $\mathrm{B}_{2}$ receptor desensitization. Collectively, these data suggest that GRK2 and GRK3 play a role in the desensitization of $\mathrm{B}_{2} \mathrm{R}$-stimulated $\left[\mathrm{Ca}^{2+}\right]_{\mathrm{i}}$ signals.

\subsection{Temporal profile of bradykinin-stimulated ERK1/2 and p38 MAPK signals}

The effects of $\mathrm{B}_{2} \mathrm{R}$ activation of ERK1/2 and p38 MAPK signals were investigated using standard immunblotting techniques (Brighton et al., 2011a; Brighton et al., 2011b). Initially, the temporal profile of bradykinin-stimulated ERK1/2 signalling was determined following the addition of maximal agonist concentration $(1 \mu \mathrm{M}$, data not shown). Bradykinin induced a rapid, yet transient increase in ERK1/2 phosphorylation peaking at $3 \mathrm{~min}$, which returned to basal levels within 5 min (Figure 4A,C). Similarly, p38 MAPK phosphorylation peaked at 3 min however the level of phosphorylation was more sustained and did not return to basal until 15 min (Figure 4B,C). Further investigation showed that bradykinin-stimulated ERK1/2 phosphorylation was attenuated following inhibition of calmodulin kinase, Src kinase, $\mathrm{Ca}^{2+}$ dependent PKCs and was also dependent on extracellular $\mathrm{Ca}^{2+}$ (see Supplementary Figure 2).

\subsection{Depletion of arrestin isoforms expression enhances ERK1/2 and p38 MAPK signalling}

Arrestins have previously been reported to modulate MAPK signalling activated by various GPCRs. Therefore we initially examined whether manipulation of arrestin expression would alter $\mathrm{B}_{2} \mathrm{R}$-induced ERK1/2 phosphorylation in ULTR cells. Transfection of ULTR cells with negative-control siRNA had no effect on basal ERK1/2 phosphorylation levels (basal means \pm S.E.M. for negative-control, $8562 \pm 732$ and non-transfected cells, $12263 \pm 2079$ ), or the magnitude or time-course of bradykinin-stimulated ERK1/2 responses compared to nontransfected cells (Figure 5A,B). In contrast, knockdown of either arrestin enhanced not only 
the peak of bradykinin-stimulated ERK1/2 phosphorylation, but markedly enhanced and prolonged the signal (Figure 5A,B).

Following negative-control siRNA transfection, the magnitude and temporal prolife of bradykinin-stimulated p38 MAPK signals, and basal p38 MAPK phosphorylation levels were comparable to those found in non-transfected cells (basal means \pm S.E.M. for negativecontrol, $9326 \pm 3275$ and non-transfected cells, $8042 \pm 2500)$. However, following siRNA depletion of arrestin2 peak p38 MAPK phosphorylation was enhanced over the first 10 min, post bradykinin challenge (Figure 6A,B). Moreover, depletion of arrestin3 resulted in a similar enhancement of bradykinin-stimulated p38 MAPK phosphorylation, which was sustained throughout the experiment (Figure 6A,B).

\subsection{Bradykinin stimulates ULTR cell migration but not proliferation}

Bradykinin signalling mediates a plethora of different physiological outcomes and has previously been reported to induce both migration and proliferation of various cells types (Figueroa et al., 2012). Therefore, we utilised standard scratch-wound or $\left[{ }^{3} \mathrm{H}\right]$ thymidine incorporation assays to examine whether bradykinin stimulated cell migration or proliferation, respectively. Initial studies showed that when compared to non-treated controls at 12 and $24 \mathrm{~h}$, scratch closure was significantly enhanced in the presence of bradykinin (Figure 7A), and was prevented by the inclusion of the $\mathrm{B}_{2} \mathrm{R}$ specific antagonist HOE140 (Supplementary Figure 3). Bradykinin-induced cell movement was approximately 50\% less than that promoted by foetal calf serum (included as a positive control; Figure 7A). Although foetal calf serum treatment doubled $\left[{ }^{3} \mathrm{H}\right]$ thymidine incorporation measured $24 \mathrm{~h}$ after treatment, bradykinin had no effect, suggesting that bradykinin-induced scratch closure was due to cell movement and not proliferation (see Supplementary Figure 4). 


\subsection{Roles for ERK1/2, p38 and Rho in bradykinin-stimulated ULTR cell migration}

GPCR-driven cell migration can be mediated through the activation of numerous downstream signalling pathways including MAPK and Rho kinase. Therefore, we utilised specific inhibitors of ERK1/2, p38 and Rho signalling to determine whether their recruitment was required for bradykinin-induced cell migration. Following inclusion of the MEK inhibitor PD98059 $(20 \mu \mathrm{M})$, bradykinin-stimulated ULTR cell migration was ablated (Figure 7B). Moreover, addition of the p38 inhibitor SB203580 (20 $\mu \mathrm{M})$ not only blocked bradykininstimulated ULTR migration but attenuated cell migration below that seen in untreated cells (Figure 7B). Finally, inclusion of the ROCK inhibitor Y27632 (20 $\mu \mathrm{M})$ also attenuated bradykinin-stimulated, but not basal ULTR cell migration (Figure 7C).

\subsection{Effects of arrestin depletion on $B_{2} R$-driven cell migration}

Collectively, our data suggest that ERK1/2, p38 MAPK and Rho kinase signalling, play roles in bradykinin-induced ULTR cell migration. Furthermore, depletion of arrestin protein expression enhances and prolongs $\mathrm{B}_{2} \mathrm{R}$-stimulated MAPK signalling. Therefore, we examined whether manipulation of arrestin expression through siRNA knockdown could alter the rate of bradykinin-stimulated ULTR cell migration. In all our previous studies where siRNA techniques have been utilised to knockdown endogenous arrestin expression, maximal depletion of arrestin proteins occurred $48 \mathrm{~h}$ after transfection. However, since the duration of the scratch assays was $72 \mathrm{~h}$, arrestin expression was determined in cells after the scratch experiments, to assess the effectiveness of the siRNA knockdown. Interestingly, $72 \mathrm{~h}$ after transfection with arrestin3 siRNA, knockdown of arrestin3 expression was similar to (Figure 8A,B) that previously observed $48 \mathrm{~h}$ post transfection (Brighton et al., 2011b). Anti-arrestin2 siRNA produced marked suppression of arrestin2 expression, although the degree of knockdown was slightly less effective after $72 \mathrm{~h}$, showing a $20 \%$ higher expression than 
when measured at $48 \mathrm{~h}$ (Brighton et al., 2011b). Importantly, in both cases each arrestin siRNA appeared selective for the targeted isoform (Figure 8A,B). Comparison of nontransfected and negative-control siRNA transfected cells showed that ULTR cell migratory behaviour was unaltered. Suppression of arrestin2 expression had no effect upon basal ULTR cell migration, yet markedly enhanced migration after $24 \mathrm{~h}$ challenge with bradykinin (Figure 8C). In contrast, knockdown of arrestin3 had no effect upon bradykinin-stimulated cell movement, yet significantly increased basal cell motility measured at 12 and $24 \mathrm{~h}$ (Figure 8C). Depletion of both arrestins enhanced bradykinin-stimulated migration to similar levels as when arrestin2 expression was suppressed (Figure 8C).

\section{Discussion}

Although the exact cause of preterm birth is still unclear, its initiation is strongly correlated with the presence of intrauterine infection (Goldenberg et al., 2008). In many ways this is unsurprising since spontaneous labour is associated with an increased synthesis and release of an array of pro-inflammatory agents, similar to that observed during infection (Agrawal et al., 2012). Indeed, several pro-inflammatory agents (e.g. histamine and prostaglandins) are known uterotonins (Bytautiene et al., 2004b; Willets et al., 2008; Willets et al., 2009), whilst others are reported to increase the expression of key elements of the myometrial contractile machinery (e.g. prostaglandin $\mathrm{F}_{2 \alpha}$ and oxytocin receptors; connexion 43; and cyclooxygenase 2) (Agrawal et al., 2012). Moreover, the presence of the kallikein-kinin system in the human uterus (Clements et al., 1994), suggests that bacterial infection is likely to enhance intrauterine bradykinin production. However, despite its central role in the inflammatory process little is currently known regarding the role that bradykinin plays in myometrial 
physiology. To rectify this shortfall, the effects of bradykinin-stimulation on the immortalised human myometrial ULTR cell-line were examined in this study. Our data show that bradykinin causes a concentration-dependent increase in $\left[\mathrm{Ca}^{2+}\right]_{i}$, which was blocked by the $\mathrm{B}_{2} \mathrm{R}$ selective antagonist HOE140. These findings support the notion that, as in the rat (Trzeciak et al., 2000), bradykinin has the potential to stimulate human uterine contractions through activation of the $\mathrm{B}_{2} \mathrm{R}$ expressed on myometrial cells. Notwithstanding, its direct ability to induce PLC activity and hence likely myometrial contractions, bradykinin is also reported to stimulate mast cell degranulation (Heitsch, 2000). Mast cell degranulation releases a plethora of inflammatory mediators, including histamine, which has been reported to induce myometrial contractions via the activation of $\mathrm{H}_{1}$ histamine receptors (Bytautiene $e t$ al., 2004a). Therefore, it is conceivable that bradykinin may have a multifunctional role in the uterus, not only acting as an uterotonin, but might also potentiate the contractile stimuli within the uterus.

In agreement with previous reports (Faussner et al., 1998), bradykinin-induced $\left[\mathrm{Ca}^{2+}\right]_{\mathrm{i}}$ signals in ULTR cells were transient and desensitized rapidly declining towards basal, even in the continued presence of agonist. GPCR desensitization is usually mediated through the recruitment of and subsequent phosphorylation by GRK proteins, which combined with previous findings that overexpression of GRKs enhanced agonist-mediated phosphorylation (Blaukat et al., 2001) suggest that one or more endogenous GRK may mediate $\mathrm{B}_{2} \mathrm{R}$ desensitization in ULTR cells. It should however be noted that the majority of previous investigations have examined $\mathrm{B}_{2} \mathrm{R}$ signalling and its regulation in model cell systems (Zimmerman et al., 2011). Although these studies highlight potential GRK/GPCR interactions, they provide little information on the roles that endogenous GRKs play in GPCR regulation. Indeed, accumulating evidence suggests that recombinant GPCRs are regulated 
very differently than when endogenously expressed in their native environment (Smith et al., 2006; Willets et al., 2009; Morris et al., 2010). Therefore, we employed a siRNA strategy to deplete ULTR cells of endogenous GRK proteins to determine their role in bradykininstimulated $\left[\mathrm{Ca}^{2+}\right]_{\mathrm{i}}$ signals. Despite the fact that when overexpressed in HEK293 cells, all the GRKs expressed in ULTR cells (Willets et al., 2009), are reported to phosphorylate the $\mathrm{B}_{2} \mathrm{R}$, only suppression of GRK2 or GRK3 was able to attenuate $B_{2} R$ desensitization. Since GRK phosphorylation is a prelude to arrestin recruitment, we subsequently suppressed arrestin2 and 3 expression to determine their roles in $B_{2} R$ desensitization. Here, depletion of either arrestin was equally effective at attenuating $\mathrm{B}_{2} \mathrm{R}$ desensitization however, combined suppression of both arrestins did not have an additive effect. Collectively, these data suggest that $\mathrm{B}_{2} \mathrm{R}$ are relatively promiscuous, recruiting GRK2 and 3 to phosphorylate the receptor before the recruitment of either arrestin 2 or 3 to promote desensitization of the $\left[\mathrm{Ca}^{2+}\right]_{\mathrm{i}}$ signals.

Increased cyclooxygenase 2 expression, accompanied by the subsequent increase in proinflammatory prostaglandins, is a key element required to switch the uterus from a quiescent to a contractile state prior to the onset of labour (Agrawal et al., 2012). Moreover, MAPK signalling is reported to play a key role in the increased expression of cyclooxygenase 2 expression (Bartlett et al., 1999; Molnar et al., 1999), highlighting their potential role in the control of prostaglandin production and labour induction. Despite evidence from model cell systems (Zimmerman et al., 2011), and fibroblasts (Hayashi et al., 2000) suggesting that the $B_{2} R$ activates MAPK signalling, the ability of $B_{2} R$ to stimulate these pathways in myometrium has not previously been reported. In ULTR cells, ERK phosphorylation was transient, closely mirroring the duration of $\left[\mathrm{Ca}^{2+}\right]_{i}$ signals, which underlies the $\mathrm{Ca}^{2+} /$ calmodulin/PKC-dependent nature of bradykinin-stimulated ERK phosphorylation. 
Contrastingly, p38 phosphorylation was more prolonged with a similar time-course to that previously observed in fibroblasts (Hayashi et al., 2000). Interestingly, in fibroblasts bradykinin-induced p38 phosphorylation stimulates the production of two pro-inflammatory cytokines, interleukin (IL) 6 and IL8, both of which are strongly correlated to initiation of labour (Christiaens et al., 2008). It is therefore conceivable that bradykinin may play a similar role in the myometrium during infections to help initiate labour. However, since the effects of MAPK activation on gene expression can be variable, further work is required to confirm a link between bradykinin signalling and alterations in contractile protein expression.

Accumulating evidence implicates arrestin proteins not only as regulators of GPCR desensitization and internalisation, but as multifunctional proteins serving as agonistregulated adaptor scaffolds, capable of directing downstream signalling events within cells (DeWire et al., 2007). Indeed, arrestin3 but not arrestin2 has a well-documented role as an ERK1/2 scaffold, retaining ERK1/2 within the cytoplasm, prolonging its activation (DeWire et al., 2007). In ULTR cells, suppression of either arrestin2 or arrestin3 produced a similar marked enhancement of the peak and plateau phases of bradykinin-stimulated ERK1/2 signalling. Since arrestin2 is incapable of directly scaffolding ERK1/2, it may be acting as previously described as a negative regulator of arrestin3-induced ERK1/2 signalling (Ahn et $a l ., 2004)$. However, and in contrast to our previous findings for oxytocin and histamine $\mathrm{H}_{1}$ receptors (Brighton et al., 2011b), it seems unlikely that arrestin3 is acting as a direct scaffold since ERK1/2 signalling is not diminished as expected following suppression of arrestin3 expression. Conversely, reduced $\mathrm{B}_{2} \mathrm{R}$ desensitization in the absence of arrestin 2 or arrestin 3 , enhances and prolongs bradykinin-stimulated $\left[\mathrm{Ca}^{2+}\right]_{\mathrm{i}}$ signals. Considering the key role that $\mathrm{Ca}^{2+}$ plays in $\mathrm{B}_{2} \mathrm{R}$ activation of ERK1/2 phosphorylation, this may explain why ERK1/2 signalling is elevated in the absence of arrestin proteins. Although previous reports suggest 
that both arrestins may also scaffold p38 (Sun et al., 2002; Bruchas et al., 2006), this seems unlikely in ULTR cells since p38 signals were not diminished following suppression of arrestin 2 or 3 expression. Indeed, in agreement with our previous findings with $\mathrm{H}_{1}$ histamine and oxytocin receptors (Brighton et al., 2011b), elevated p38 signalling is likely a consequence of the inability to promote $\mathrm{B}_{2} \mathrm{R}$ desensitization in the absence of arrestins.

Aside from activating PLC and MAPK signalling pathways, bradykinin is also reported to induce cellular proliferation and migration (Figueroa et al., 2012). Herein, we report for the first time that bradykinin induces myometrial cell movement, but not proliferation. Although mediated through the activation of a plethora of different signalling pathways, in ULTR cells $\mathrm{B}_{2} \mathrm{R}$-stimulated cell movement appears to be dependent on both p38 and ERK1/2 MAPKs, and Rho kinase signalling. Indeed, all three inhibitors block basal cell migration to varying degrees which may suggest that MAPK and Rho kinases play a role in agonist-independent ULTR cell movement. Furthermore, both arrestin 2 and 3 have been implicated in the regulation of GPCR-mediated cell migration through a variety of mechanisms. For example, arrestin3 enhances, whilst arrestin2 inhibits Rho-dependent membrane blebbing, modulating cell movement via an actin-reliant mechanism (Godin et al., 2010). The fact that $\mathrm{B}_{2} \mathrm{R}$-driven cell movement is enhanced following arrestin2 knockdown, may support this role for arrestin3 in agonist-stimulated motility. However, the failure to inhibit migration in the absence of arrestin3 suggests that ULTR movement is also reliant on alternative mechanisms. Recent evidence highlights a role for arrestin2 as the dominant scaffold for cofilin-specific phosphatase (Zoudilova et al., 2007). Indeed, arrestin binding increases cofilin-specific phosphatase activity, leading to actin filament severing to promote cell movement in a $G$ protein/ $\mathrm{Ca}^{2+}$-independent manner (Zoudilova et al., 2007). Our data both support and contradict such a role for arrestin2 in ULTR cells since in the absence of arrestin3 un- 
stimulated cell motility was enhanced, suggesting that arrestin2 may have more access to cofilin-specific phosphatase, thus promoting its action and cell movement. Conversely, as ULTR cell movement is unaltered in the absence of arrestin2 this would argue against this assumption. Although the arrestin-dependent mechanisms outlined above may play roles in agonist-mediated ULTR cell movement, evidence from HEK293 cells suggests that the answer may be far simpler. Indeed, expression of a mutant $B_{2} R$ which failed to recruit arrestin proteins, not only led to enhanced PLC, and ERK1/2 signalling, but increased cell

motility (Zimmerman et al., 2011). Therefore, it seems likely that a similar scenario occurs in ULTR cells, with increased $B_{2} R$ signalling underling increased motility, possibly regulated by arrestin 2 more than 3 .

\section{Conclusion}

In summary we show that bradykinin activates pro-contractile signalling pathways within human myometrial cells and arrestins play vital roles in regulating these signalling pathways. Collectively, our data suggest that bradykinin not only acts as an utertonin but has the potential to enhance the contractile environment of the uterus, via activation of MAPK signalling. 


\section{References}

Agrawal V, Hirsch E (2012). Intrauterine infection and preterm labor. Sem Fetal \& Neontl Med 17(1): 12-19.

Ahn S, Wei H, Garrison TR, Lefkowitz RJ (2004). Reciprocal regulation of angiotensin receptor-activated extracellular signal-regulated kinases by beta-arrestins 1 and 2 . J Biol Chem 279(9): 7807-7811.

Bartlett SR, Sawdy R, Mann GE (1999). Induction of cyclooxygenase-2 expression in human myometrial smooth muscle cells by interleukin-1 $\beta$ : involvement of p38 mitogen-activated protein kinase. J Physiol 520 Pt 2: 399-406.

Blaes N, Girolami JP (2013). Targeting the 'Janus face' of the $\mathrm{B}_{2}$-bradykinin receptor. Expt Opin Therapeut Targ 17(10): 1145-1166.

Blaukat A, Pizard A, Breit A, Wernstedt C, Alhenc-Gelas F, Muller-Esterl W, et al. (2001). Determination of bradykinin B2 receptor in vivo phosphorylation sites and their role in receptor function. J Biol Chem 276(44): 40431-40440.

Blaukat A, Pizard A, Rajerison RM, Alhenc-Gelas F, Muller-Esterl W, Dikic I (1999). Activation of mitogen-activated protein kinase by the bradykinin $\mathrm{B}_{2}$ receptor is independent of receptor phosphorylation and phosphorylation-triggered internalization. FEBS letters 451(3): 337-341. 
Brighton PJ, Marczylo TH, Rana S, Konje JC, Willets JM (2011a). Characterization of the endocannabinoid system, $\mathrm{CB}_{1}$ receptor signalling and desensitization in human myometrium. Brit J Pharmacol 164(5): 1479-1494.

Brighton PJ, McDonald J, Taylor AH, Challiss RA, Lambert DG, Konje JC, et al. (2009). Characterization of anandamide-stimulated cannabinoid receptor signaling in human ULTR myometrial smooth muscle cells. Mol Endocrinol 23(9): 1415-1427.

Brighton PJ, Rana S, Challiss RJ, Konje JC, Willets JM (2011b). Arrestins differentially regulate histamine- and oxytocin-evoked phospholipase $\mathrm{C}$ and mitogen-activated protein kinase signalling in myometrial cells. Brit J Pharmacol 162(7): 1603-1617.

Bruchas MR, Macey TA, Lowe JD, Chavkin C (2006). $\kappa$ opioid receptor activation of p38 MAPK is GRK3- and arrestin-dependent in neurons and astrocytes. J Biol Chem 281(26): 18081-18089.

Bytautiene E, Romero R, Vedernikov YP, El-Zeky F, Saade GR, Garfield RE (2004a). Induction of premature labor and delivery by allergic reaction and prevention by histamine $\mathrm{H}_{1}$ receptor antagonist. Am J Obstet \& Gynecol 191(4): 1356-1361. 
Bytautiene E, Vedernikov YP, Saade GR, Romero R, Garfield RE (2004b). Degranulation of uterine mast cell modifies contractility of isolated myometrium from pregnant women. Am J Obstet \& Gynecol 191(5): 1705-1710.

Christiaens I, Zaragoza DB, Guilbert L, Robertson SA, Mitchell BF, Olson DM (2008). Inflammatory processes in preterm and term parturition. J Reproductive Immunol 79(1): 5057.

Clements J, Mukhtar A, Ehrlich A, Yap B (1994). Glandular kallikrein gene expression in the human uterus. Brazil J Med \& Biol Res 27(8): 1855-1863.

Couture R, Harrisson M, Vianna RM, Cloutier F (2001). Kinin receptors in pain and inflammation. Europ J Pharmacol 429(1-3): 161-176.

DeWire SM, Ahn S, Lefkowitz RJ, Shenoy SK (2007). $\beta$-arrestins and cell signaling. Annu Rev Physiol 69: 483-510.

Faussner A, Proud D, Towns M, Bathon JM (1998). Influence of the cytosolic carboxyl termini of human B1 and B2 kinin receptors on receptor sequestration, ligand internalization, and signal transduction. J Biol Chem 273(5): 2617-2623.

Figueroa CD, Ehrenfeld P, Bhoola KD (2012). Kinin receptors as targets for cancer therapy. Expt Opin Therapeut Targ 16(3): 299-312. 
Fleming I, Fisslthaler B, Busse R (1995). Calcium signaling in endothelial cells involves activation of tyrosine kinases and leads to activation of mitogen-activated protein kinases. Circ Res 76(4): 522-529.

Godin CM, Ferguson SS (2010). The angiotensin II type 1 receptor induces membrane blebbing by coupling to Rho A, Rho kinase, and myosin light chain kinase. Mol Pharmacol 77(6): 903-911.

Goldenberg RL, Culhane JF, Iams JD, Romero R (2008). Epidemiology and causes of preterm birth. Lancet 371(9606): 75-84.

Hayashi R, Yamashita N, Matsui S, Fujita T, Araya J, Sassa K, et al. (2000). Bradykinin stimulates IL-6 and IL-8 production by human lung fibroblasts through ERK- and p38 MAPK-dependent mechanisms. Eur Resp J 16(3): 452-458.

Heitsch $\mathrm{H}$ (2000). Bradykinin $\mathrm{B}_{2}$ receptor as a potential therapeutic target. Drug News Perspect 13(4): 213-225.

Janicek F, Franova S, Nosalova G, Visnovsky J (2007). In vitro contractile response of human myometrium to oxytocin, PGF2 $\alpha$, bradykinin and ET-1. Bratislavske lekarske listy 108(4-5): 174-178. 
Lamb ME, De Weerd WF, Leeb-Lundberg LM (2001). Agonist-promoted trafficking of human bradykinin receptors: arrestin- and dynamin-independent sequestration of the B2 receptor and bradykinin in HEK293 cells. Biochem J 355(Pt 3): 741-750.

Leeb-Lundberg LM, Marceau F, Muller-Esterl W, Pettibone DJ, Zuraw BL (2005). International union of pharmacology. XLV. Classification of the kinin receptor family: from molecular mechanisms to pathophysiological consequences. Pharmacol Rev 57(1): 27-77.

Marceau F, Hess JF, Bachvarov DR (1998). The B1 receptors for kinins. Pharmacol Rev 50(3): 357-386.

Molnar M, Rigo J, Jr., Romero R, Hertelendy F (1999). Oxytocin activates mitogen-activated protein kinase and up-regulates cyclooxygenase- 2 and prostaglandin production in human myometrial cells. Am J Obstet \& Gynecol 181(1): 42-49.

Morris GE, Nelson CP, Standen NB, Challiss RA, Willets JM (2010). Endothelin signalling in arterial smooth muscle is tightly regulated by $G$ protein-coupled receptor kinase 2 . Cardiovasc Res (85): 424-433.

Murone C, Chai SY, Muller-Esterl W, Mendelsohn FA, Clements J (1999). Localization of bradykinin B2 receptors in the endometrium and myometrium of rat uterus and the effects of estrogen and progesterone. Endocrinol 140(7): 3372-3382. 
Perez-Reyes N, Halbert CL, Smith PP, Benditt EP, McDougall JK (1992). Immortalization of primary human smooth muscle cells. Proc Natl Acad Sci 89(4): 1224-1228.

Senior J, Whalley ET (1976). The influence of drugs on the kinin-forming system in relation to pregnancy and parturition in the rat. J Reprod \& Fertil 47(2): 319-323.

Smith MP, Ayad VJ, Mundell SJ, McArdle CA, Kelly E, Lopez Bernal A (2006). Internalization and desensitization of the oxytocin receptor is inhibited by Dynamin and clathrin mutants in human embryonic kidney 293 cells. Mol Endocrinol 20(2): 379-388.

Sun Y, Cheng Z, Ma L, Pei G (2002). $\beta$-arrestin2 is critically involved in CXCR4-mediated chemotaxis, and this is mediated by its enhancement of p38 MAPK activation. $J$ Biol Chem 277(51): 49212-49219.

Trzeciak HI, Kozik W, Melhem S, Kania A, Dobrowolski D, Prahl A, et al. (2000). New bradykinin analogs in contraction of rat uterus. Peptides 21(6): 829-834.

Wassdal I, Nicolaysen G, Iversen JG (1998). Bradykinin causes contraction in rat uterus through the same signal pathway as oxytocin. Acta Physiol Scandinavica 164(1): 47-52.

Willets JM, Brighton PJ, Mistry R, Morris GE, Konje JC, Challiss RA (2009). Regulation of oxytocin receptor responsiveness by $\mathrm{G}$ protein-coupled receptor kinase 6 in human myometrial smooth muscle. Mol Endocrinol 23(8): 1272-1280. 
Willets JM, Challiss RA, Nahorski SR (2003). Non-visual GRKs: are we seeing the whole picture? Trends Pharmacol Sci 24(12): 626-633.

Willets JM, Nahorski SR, Challiss RA (2005). Roles of phosphorylation-dependent and independent mechanisms in the regulation of $\mathrm{M}_{1}$ muscarinic acetylcholine receptors by $\mathrm{G}$ protein-coupled receptor kinase 2 in hippocampal neurons. J Biol Chem 280(19): 1895018958.

Willets JM, Taylor AH, Shaw H, Konje JC, Challiss RA (2008). Selective regulation of $\mathrm{H}_{1}$ histamine receptor signaling by $\mathrm{G}$ protein-coupled receptor kinase 2 in uterine smooth muscle cells. Mol Endocrinol 22(8): 1893-1907.

Yusuf S, Sleight P, Pogue J, Bosch J, Davies R, Dagenais G (2000). Effects of an angiotensin-converting-enzyme inhibitor, ramipril, on cardiovascular events in high-risk patients. The Heart Outcomes Prevention Evaluation Study Investigators. New Eng J Medicine 342(3): 145-153.

Zimmerman B, Simaan M, Akoume MY, Houri N, Chevallier S, Seguela P, et al. (2011). Role of ssarrestins in bradykinin B2 receptor-mediated signalling. Cellular signalling 23(4): 648-659. 
Zoudilova M, Kumar P, Ge L, Wang P, Bokoch GM, DeFea KA (2007). $\beta$-arrestin-dependent regulation of the cofilin pathway downstream of protease-activated receptor-2. J Biol Chem 282(28): 20634-20646.

\section{Figure Legends}

Figure 1. Characterization of bradykinin induced $\left[\mathrm{Ca}^{2+}\right]_{\mathrm{i}}$ changes in myometrial cells. ULTR cells were loaded with Fluo4AM (3 $\mu \mathrm{M}$, for $1 \mathrm{~h})$ and agonist-induced $\left[\mathrm{Ca}^{2+}\right]_{\mathrm{i}}$ changes monitored using a NovoStar imaging system (see Methods). A) Representative traces showing typical temporal profiles of $\left[\mathrm{Ca}^{2+}\right]_{\mathrm{i}}$ changes after stimulation with a maximal concentration of bradykinin $(1 \mu \mathrm{M})$. B) Concentration-response curves generated after stimulation with varying concentrations of bradykinin. Data are shown as means \pm S.E.M. from 6 separate experiments. Representative traces $(\mathbf{C})$ and cumulative data $(\mathbf{D})$ showing that bradykinin induced $\left[\mathrm{Ca}^{2+}\right]_{\mathrm{i}}$ changes are completely blocked following the inclusion of the $B_{2} R$ specific antagonist HOE140, but not the $B_{1}$ receptor specific antagonist R715 (whose addition is noted by the long bar). Data are presented as means \pm S.E.M. for the $\%$ change in R2/R1 ratio for between 48-83 cells from at least 4 separate experiments. Bradykinininduced $\left[\mathrm{Ca}^{2+}\right]_{\mathrm{i}}$ changes were significantly suppressed in the presence of $\mathrm{HOE} 140(* * p<0.01$; one-way ANOVA; Dunnett's post-hoc test).

Figure 2. Desensitisation and re-sensitization kinetic of $B_{2} R$-stimulated $\left[\mathrm{Ca}^{2+}\right]_{i}$ changes.

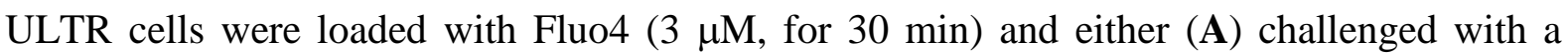


single maximal bradykinin $(1 \mu \mathrm{M})$ concentration for 4 min (shown by the bar); or $(\mathbf{B}, \mathbf{C})$ subjected to the standard R1/R2 desensitization protocol: cells were stimulated with bradykinin $(1 \mu \mathrm{M}, 30 \mathrm{sec})(\mathrm{R} 1)$, followed by a variable period of 5,10 , or $15 \mathrm{~min}$ before further bradykinin $(1 \mu \mathrm{M}, 30 \mathrm{sec})$ exposure (R2). Representative traces from single cells with either a 5 (B) or 15 (C) min wash period are shown. $\mathrm{B}_{2} \mathrm{R}$ desensitization was determined as the relative change in $\mathrm{R} 2$ response compared to R1. (D) Cumulative data shown as means \pm S.E.M. from 16-31 cells from at least 4 different experiments.

Figure 3. Arrestin 2 and 3 depletion enhances bradykinin stimulated $\left[\mathrm{Ca}^{2+}\right]_{\mathrm{i}}$ signalling and attenuates $B_{2} R$ desensitization. ULTR cells were transfected with siRNAs against arrestin 2 (AR2, $100 \mathrm{nM})$, arrestin $3(\mathrm{AR} 3,10 \mathrm{nM})$ or negative-control (NC, $100 \mathrm{nM})$ siRNA for $48 \mathrm{~h}$. Bradykinin $(1 \mu \mathrm{M})(\mathbf{A})\left[\mathrm{Ca}^{2+}\right]_{\mathrm{i}}$ signals were examined in the presence (black) or absence of arrestin2 (grey) or arrestin3 (broken line) using the NovoStar imaging system (see Methods). Mean trace data are shown from $n=4$ experiments and S.E.M. and error bars are omitted for clarity. $\mathrm{B}_{2} \mathrm{R}$ desensitization was assessed using the standard $\mathrm{R} 1 / \mathrm{R} 2$ desensitization protocol: cells were stimulated with bradykinin $(1 \mu \mathrm{M}, 30 \mathrm{sec})(\mathrm{R} 1)$, followed by a $5 \mathrm{~min}$ washout before further bradykinin $(1 \mu \mathrm{M}, 30 \mathrm{sec})$ exposure (R2). Representative traces from single cells are shown (B) in the presence (black) or absence of arrestin2 (grey) or arrestin3 (broken line). Representative traces from single cells are shown $(\mathbf{C})$ in the presence of GRKs (black) or absence of GRK2 (grey), or GRK3 (broken line). Cumulative data (D) show a significant $\left(* * p<0.01 ;{ }^{* * *} p<0.001\right.$; one-way ANOVA; Dunnett's post-hoc test) decrease in the extent of $\mathrm{B}_{2} \mathrm{R}$ desensitization after depletion of endogenous arrestin2, arrestin3, GRK2 or GRK3 expression, when compared to negative-control transfected cells. Data are presented as means \pm S.E.M. for the $\%$ change in R2/R1 ratio for between $61-181$ cells from at least 6 separate experiments. 
Figure 4. Temporal prolife of bradykinin induced MAPK signalling. Confluent cells were serum-starved for $24 \mathrm{~h}$ prior to agonist stimulation, and pERK1/2 or pp38 levels determined by standard immunoblotting techniques (upper panels). To ensure that all samples contained the same levels of protein, total ERK or p38 levels were determined by running additional gels in parallel with the detection of pERK and pp38 (lower panels). Representative immunoblots show the time-course of bradykinin $(1 \mu \mathrm{M})$ induced ERK1/2 (A), and p38 phosphorylation (B). Cumulative data show significant $(* * p<0.01$; one-way ANOVA; Dunnett's post-hoc test) increases in MAPK phosphorylation when compared to non-treated cells.

Figure 5. Arrestin knockdown enhanced and prolongs bradykinin stimulated ERK1/2 phosphorylation. ULTR cells were transfected with siRNAs against arrestin2 (AR2, $100 \mathrm{nM})$, arrestin3 (AR3, $10 \mathrm{nM})$ or negative control (NC, $100 \mathrm{nM})$. After $24 \mathrm{~h}$ cells were serumstarved for a further $24 \mathrm{~h}$ and then stimulated with bradykinin $(1 \mu \mathrm{M})$. Cells were lysed and pERK1/2 immunoreactivity determined by standard immunoblotting techniques (upper panels). To ensure that all samples contained the same levels of protein, total ERK levels were determined by running additional gels in parallel with the detection of pERK. Representative immunoblots are show for bradykinin $(1 \mu \mathrm{M})$ (A) stimulated ERK1/2 phosphorylation in the presence or absence of arrestin2 or arrestin3. (B) Cumulative densitometric analysis of bradykinin-stimulated ERK1/2 phosphorylation. Data are shown as means \pm SEM for 5 separate experiments. Depletion of either arrestin 2 or 3 enhanced and prolonged $\mathrm{B}_{2} \mathrm{R}$ stimulated ERK1/2 phosphorylation $\left({ }^{*} p<0.05\right.$, ** $p<0.01$, *** $p<0.001$ two- 
way ANOVA; Bonferroni's post-hoc test) when compared to negative control transfected cells.

Figure 6. Arrestins differentially regulate bradykinin stimulated p38 signalling. ULTR cells were transfected with siRNAs against arrestin2 (AR2, $100 \mathrm{nM})$, arrestin3 (AR3, $10 \mathrm{nM})$ or negative control (NC, $100 \mathrm{nM})$. After $24 \mathrm{~h}$ cells were serum-starved for a further $24 \mathrm{~h}$ and then stimulated with bradykinin $(1 \mu \mathrm{M})$. Cells were lysed and pp38 immunoreactivity determined by standard immunoblotting techniques (upper panels). To ensure that all samples contained the same levels of protein, total p38 levels were determined by running additional gels in parallel with the detection of pp38 (lower panels). Representative immunoblots are show for bradykinin $(1 \mu \mathrm{M})(\mathbf{A})$ stimulated p38 phosphorylation in the presence or absence of arrestin2 or arrestin3. Cumulative densitometric analysis of bradykinin (B) stimulated p38 phosphorylation. Data are shown as means \pm SEM for 5 separate experiments. Depletion of arrestin3 enhanced and prolonged $\mathrm{B}_{2} \mathrm{R}$ stimulated $\mathrm{p} 38$ phosphorylation $\left({ }^{*} p<0.05\right.$, ${ }^{*} p<0.01$, *** $p<0.001$ two-way ANOVA; Bonferroni's post-hoc test), whilst arrestin2 depletion enhanced p38 phosphorylation only at 5 and $10 \mathrm{~min}$; when compared to negative control transfected cells.

Figure 7. Bradykinin stimulates ULTR cell migration. ULTR cells were prepared, serum starved and scratched as described in the Methods section, before being incubated with bradykinin $(1 \mu \mathrm{M})$ or foetal calf serum $(10 \% \mathrm{v} / \mathrm{v})$. Photographs of each scratch were taken at $(0,12$, and $24 \mathrm{~h}$ after scratching) and the width of the scratch measured as described in the Methods Section. (A) Bradykinin (Brad) and foetal calf serum (FCS) on cell movement are shown significantly increased cell motility $\left(* p<0.05\right.$, **p $*^{*}<0.01$, ***p $<0.01$ two way 
ANOVA; Bonferonni's post-hoc test), when compared to non-treated cells. To assess whether bradykinin-stimulated movement was regulated by MAPKs or Rho activity, ULTR cells were incubated with the MEK inhibitor (PD 98059) (B), the p38 inhibitor SB203580 (C), or ROCK inhibitor (Y27632) (D), for 30 min before addition of agonists and throughout the assay. Inclusion of all compounds prevented bradykinin-induced cell motility $\left({ }^{*} \mathrm{p}<0.05\right.$, $*^{*} \mathrm{p}<0.01, * * * p<0.01$ two way ANOVA; Bonferonni's post-hoc test) when compared to vehicle treated cells.

Figure 8. Arrestin2 depletion enhances bradykinin induced cell migration. ULTR cells were prepared serum starved and scratched as described in the Methods section. Photographs of each scratch were taken at (before, 6, 12, and $24 \mathrm{~h}$ after scratching). After the final photographs were taken cells were lysed, and arrestin expression determined via Western blotting. Representative immunoblots (A) show the level of arrestin2 (upper panel) or arrestin3 (lower panel) expression following $72 \mathrm{~h}$ treatment with either anti-arrestin2 (100 $\mathrm{nM})$, anti-arrestin3 $(10 \mathrm{nM})$ or negative-control $(100 \mathrm{nM})$ siRNAs. Cumulative data $(\mathrm{n}=4$ separate experiments) show the relative arrestin 2 or 3 expression compared to negative control treated cells $(\mathbf{B})$. Data show a significant $(* * p<0.01$, one-way ANOVA; Dunnett's post-hoc test) suppression of arrestin 2 or arrestin 3 expression when compared to negative control treated cells. The effects of siRNA-dependent arrestin2 (AR2) or arrestin3 (AR3) depletion on bradykinin (Brad)-stimulated ULTR cell motility are shown (C). Significant $\left({ }^{*} p<0.05, * * p<0.01, * * * p<0.01\right.$ two way ANOVA; Bonferonni's post-hoc test) increases in cell motility when compared to vehicle treated negative control (NC) siRNA transfected cells shown. Furthermore, arrestin2 knockdown enhanced bradykinin-induced ULTR cell movement at $24 \mathrm{~h}\left({ }^{++} p<0.001\right.$ two way ANOVA; Bonferonni's post-hoc test), when compared to bradykinin treated negative control (NC) siRNA transfected cells. 


\section{Supplementary Figures}

Supplemental Figure 1. Assessment of siRNA mediated arrestin or GRK depletion. ULTR cells were transfected with siRNAs against arrestin2, arrestin3 or negative control siRNA or siRNA constructs targeting endogenous GRK2, GRK3, GRK5 and GRK6 as described in Materials and Methods section. After $48 \mathrm{~h}$ cells were lysed and $40 \mu \mathrm{g}$ of protein loaded per lane for SDS-PAGE separation and immunoblotting. A) Representative immunblot showing arrestin 2 expression following treatment with negative control (NC; lane 1) or anti-arrestin 2 (lane 2). B) Representative immunblot showing arrestin 3 expression following transfection with negative control (NC; lane 1) or anti-arrestin 3 (lane 2). (C) Representative immunoblots showing anti-GRK siRNAs on endogenous GRK expression in ULTR cells are shown: lane 1, negative control (NC); lane 2, anti-GRK2; lane 3, anti-GRK3; lane 4, anti-GRK5; lane 5, anti-GRK6. Densitometric analysis was undertaken on all blots and data are shown to highlight changes in arrestin (D) or GRK2, GRK3, GRK5 and GRK6 expression (E) in ULTR cells following anti-arrestin, anti-GRK2, anti-GRK3, anti-GRK5 or anti-GRK6 siRNA treatments. Data are shown as means \pm SEM for 4-6 separate experiments where arrestin/GRK isoenzyme expression was compared to cells transfected with a negative control siRNA $\left(=100 \%\right.$ for each arrestin or GRK isoenzyme). ${ }^{* *} p<0.01$ (one-way ANOVA; Dunnett's post-hoc test) comparing anti-arrestin/anti-GRK2/anti-GRK3/anti-GRK5/antiGRK6 siRNA treatments with respective negative control siRNA treatments.

Supplementary Figure 2. Characterisation of $\mathrm{B}_{2} \mathrm{R}$-stimulated ERK1/2 signalling in ULTR cells. Confluent cells were serum-starved for $24 \mathrm{~h}$ prior to agonist stimulation, and pERK1/2 levels determined by standard immunoblotting techniques (upper panels). To ensure that all samples contained the same levels of protein, total ERK1/2 levels were determined by 
running additional gels in parallel with the detection of pERK1/2 (lower panels). Representative immunoblots are displayed showing bradykinin $(1 \mu \mathrm{M}, 3$ min)-stimulated ERK signals in the presence or absence of (A) the calmodulin-kinase inhibitor KN62 $(5 \mu \mathrm{M})$ (B) the PKC inhibitor Go6976 (1 $\mu \mathrm{M}$, for 15 min prior to agonist challenge) (C) the Srckinase inhibitor PP1 (5 $\mu \mathrm{M}, 30$ min prior to agonist challenge) or (D) presence or nominal absence of extracellular $\mathrm{Ca}^{2+}$ (i.e. in nominally $\mathrm{Ca}^{2+}$-free Krebs). (E) Cumulative data show significant $\left(* p<0.05, *^{*} p<0.01\right.$; one-way ANOVA; Dunnett's post-hoc test) inhibition of bradykinin-stimulated ERK1/2 phosphorylation when compared to vehicle-treated cells.

Supplementary Figure 3. Bradykinin induced cell migration is prevented by the $B_{2} R$ antagonist HOE140. ULTR cells were prepared, serum starved and scratched as described in the Methods section, before being incubated with bradykinin $(1 \mu \mathrm{M})$ in the absence or presence of HOE140 (1 $\mu \mathrm{M}$, added 30 min prior to bradykinin challenge). Bradykinin significantly increased cell motility $\left({ }^{*} p<0.05,{ }^{*} p<0.01\right.$, two way ANOVA; Bonferonni's post-hoc test), when compared to non-treated, or HOE140 treated cells. Data are shown as means \pm SEM for 6 separate experiments.

Supplementary Figure 4. Bradykinin does not induce ULTR cell proliferation. ULTR cells were seeded onto 24 well plates at a density of $4 \times 10^{4} /$ well and left to settle for 24 hours. Subsequently, these cells were washed with PBS and incubated with serum free media for a period of 48 hours. Following this period, media was changed for either serum free media, media containing foetal calf serum $(\mathrm{FCS}, 10 \% \mathrm{v} / \mathrm{v})$ or bradykinin $(1 \mu \mathrm{M})$ at the required concentrations and cells incubated overnight at $37^{\circ} \mathrm{C}$. The following morning, $\left[{ }^{3} \mathrm{H}\right]$ thymidine $(1 \mu \mathrm{Ci})$ was added to each of the wells and incubated for 4 hours. Media was then aspirated 
and cells washed with basal media before incubated with $0.5 \mathrm{M}$ TCA for 1 hour. Plates were then washed twice with PBS and incubated with $0.5 \mathrm{M} \mathrm{NaOH}$ for $20 \mathrm{~min}$. Samples were taken and transferred to scintillation vials and subjected to scintillation counting. $\left[{ }^{3} \mathrm{H}\right]$ Thymidine incorporation is expressed as mean d.p.m. \pm S.E.M., and only FCS enhanced $\left[{ }^{3} H\right]$ thymidine incorporation above basal levels after $24 \mathrm{~h}\left(*^{*} p<0.01\right.$; one-way ANOVA; Dunnett's post-hoc test). 


\section{Highlights}

Bradykinin activates $\mathrm{Ca}^{2+}$ signals via bradykinin $\mathrm{B}_{2}$ receptors in myometrial cells.

Arrestin2/3 depletion attenuates bradykinin $\mathrm{B}_{2}$ receptor desensitization.

Arrestin2/3 depletion enhanced bradykinin $\mathrm{B}_{2}$ receptor ERK1/2 signalling.

Arrestin3 depletion increased and prolonged bradykinin-stimulated p38 MAPK signals.

Bradykinin activates pro-contractile signalling pathways in the human myometrium. 


\section{Figure 1}

A

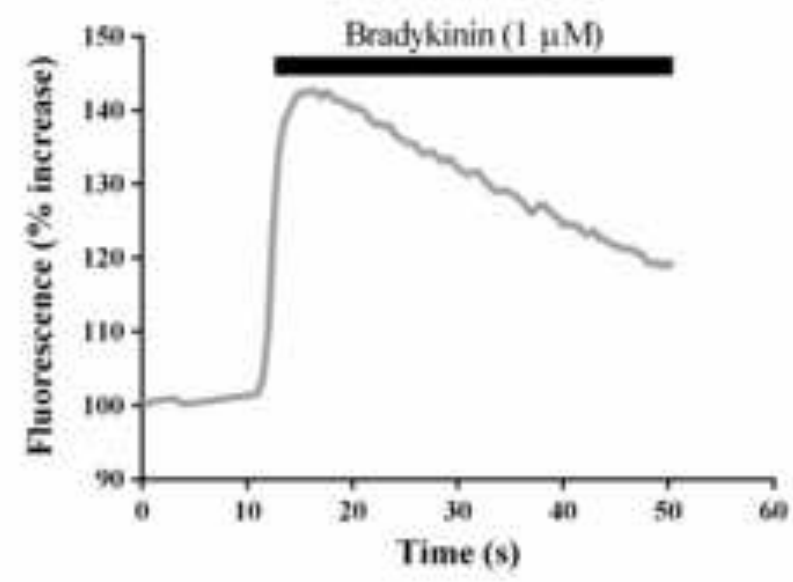

C

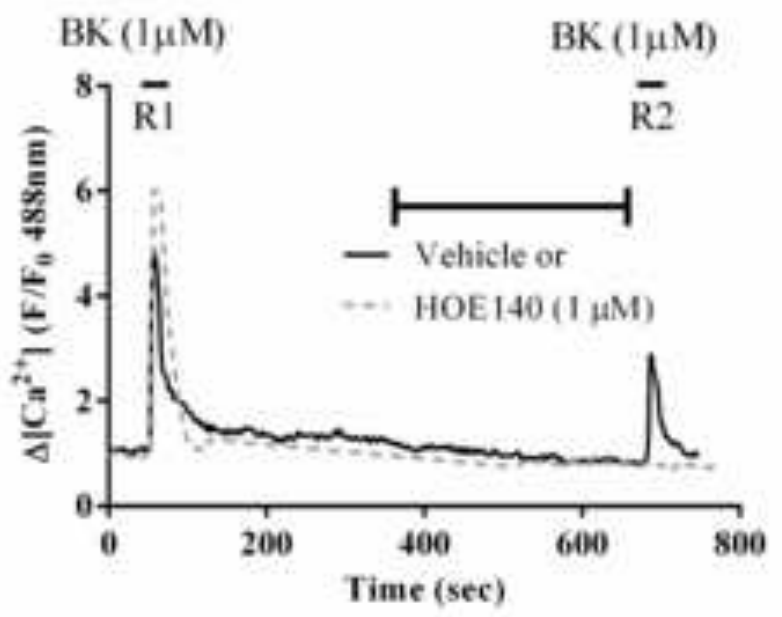

B

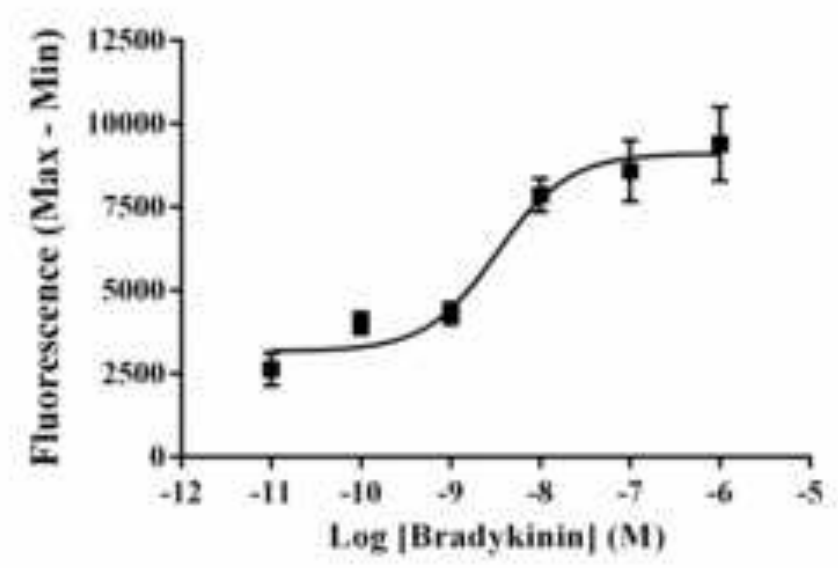

D

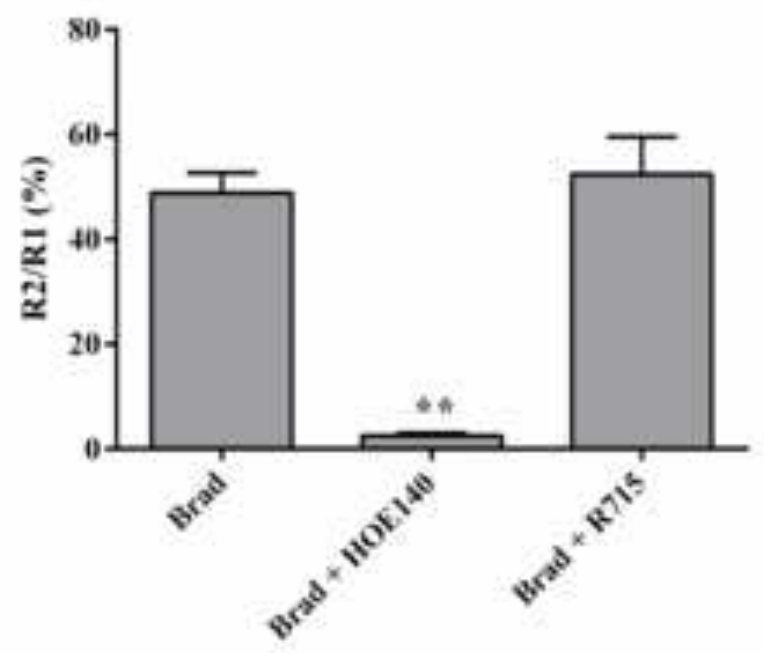




\section{Figure 2}

A

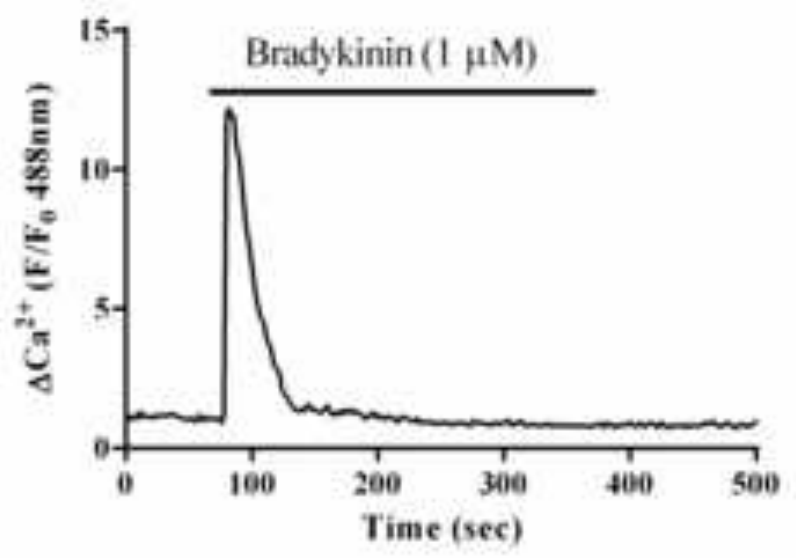

C

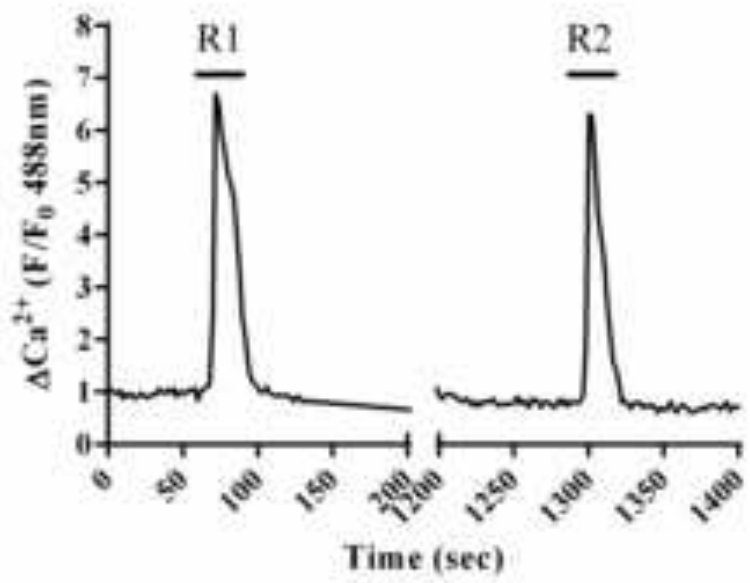

B

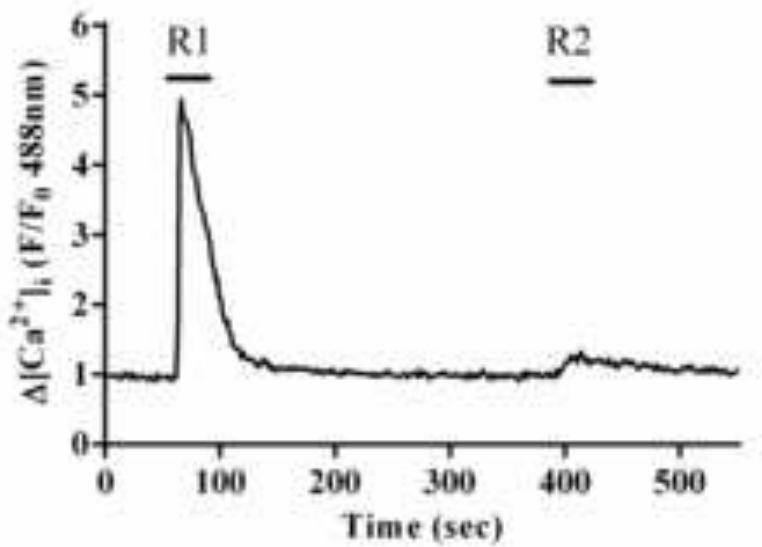

D

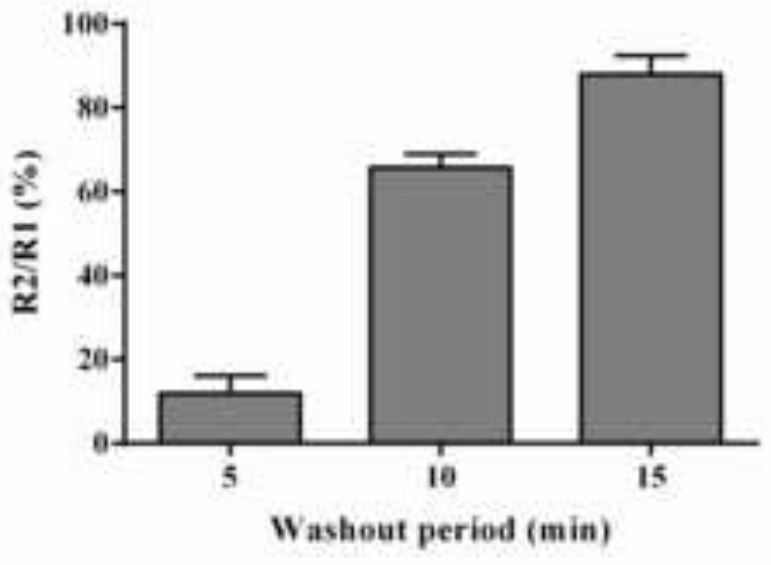


Figure 3

A

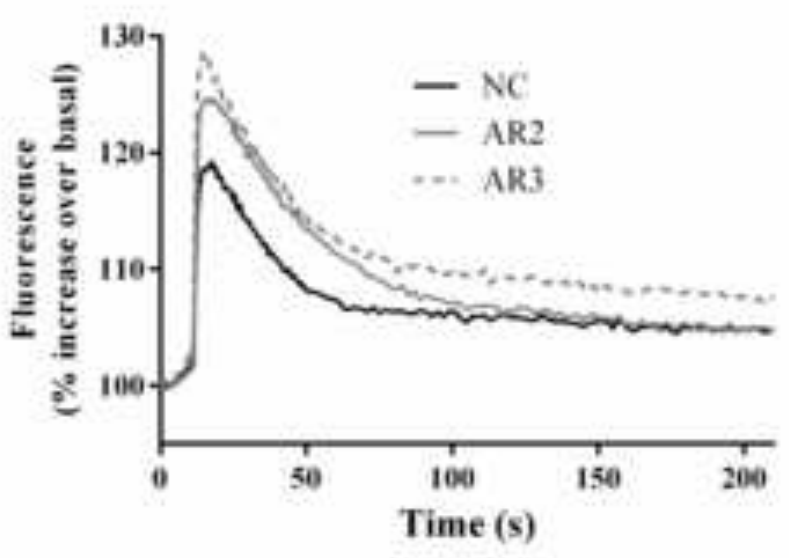

C

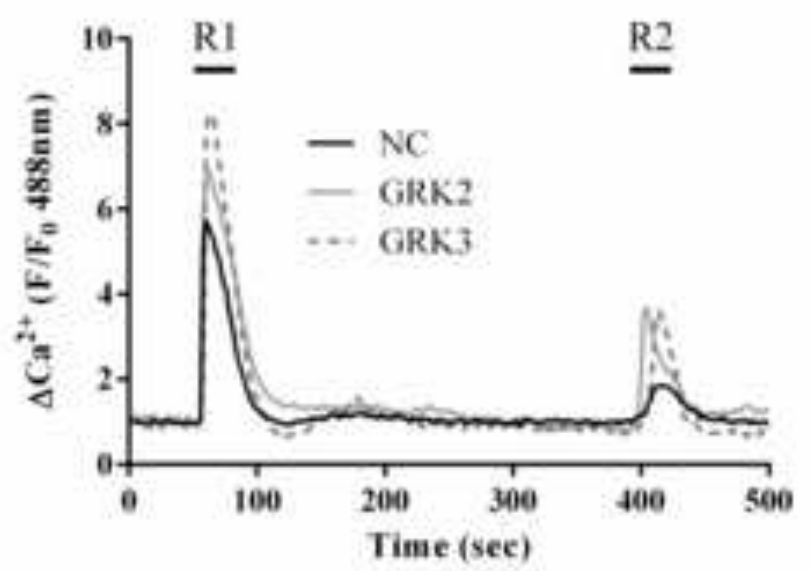

B

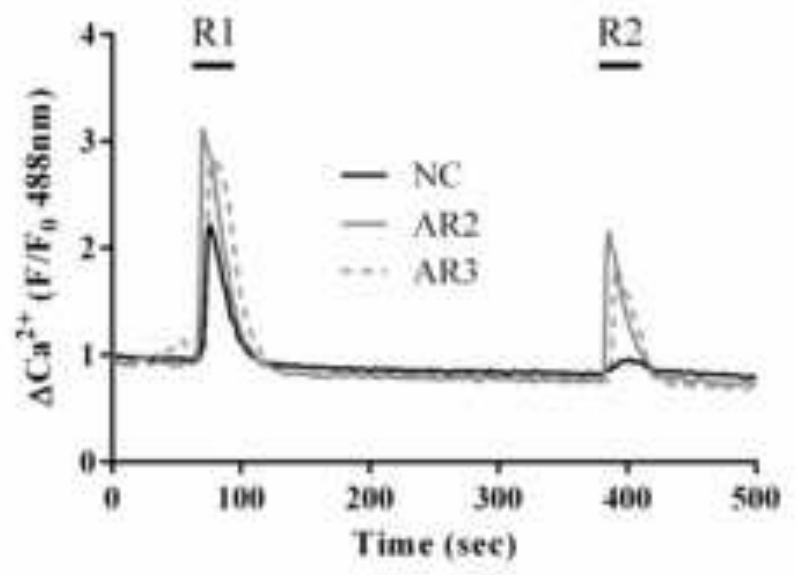

D

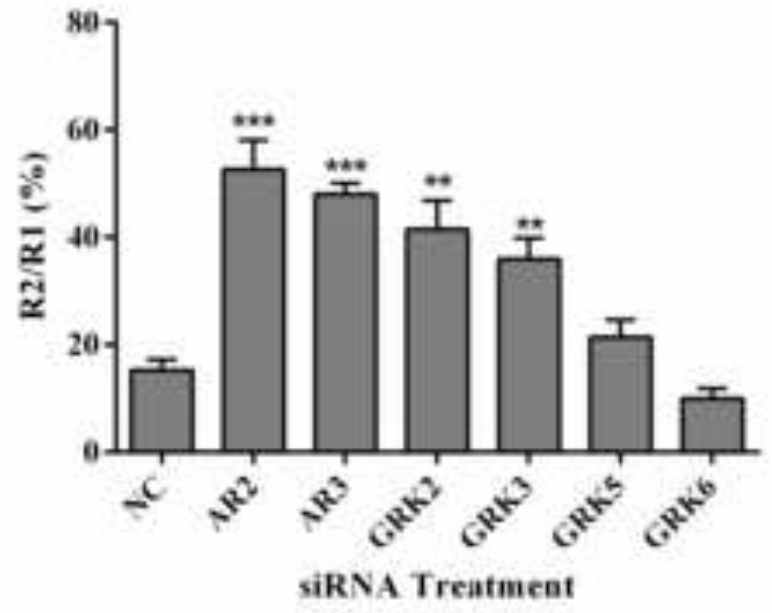




\section{Figure}

Click here to download high resolution image

\section{Figure 4}
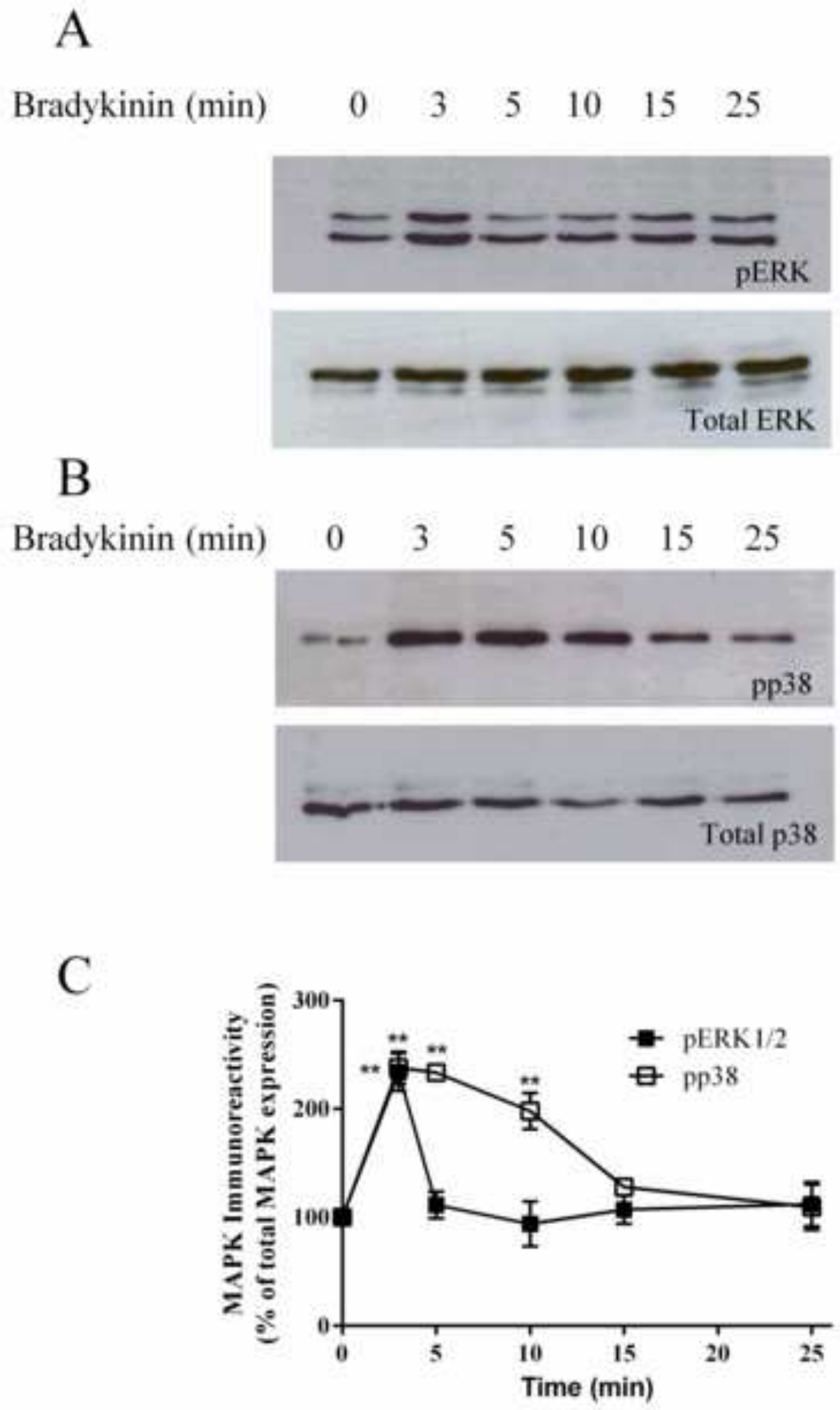
Click here to download high resolution image

\section{Figure 5}

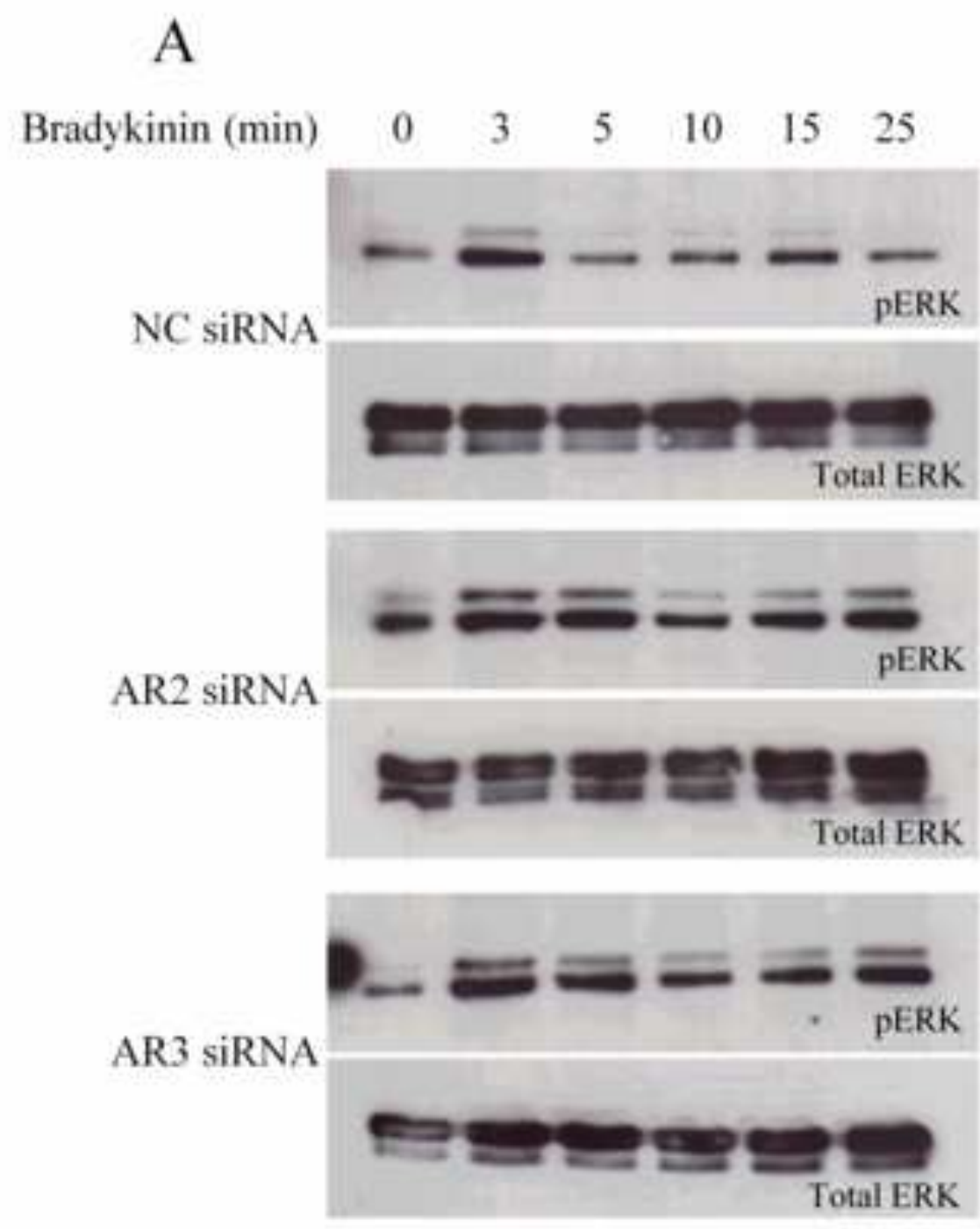

B

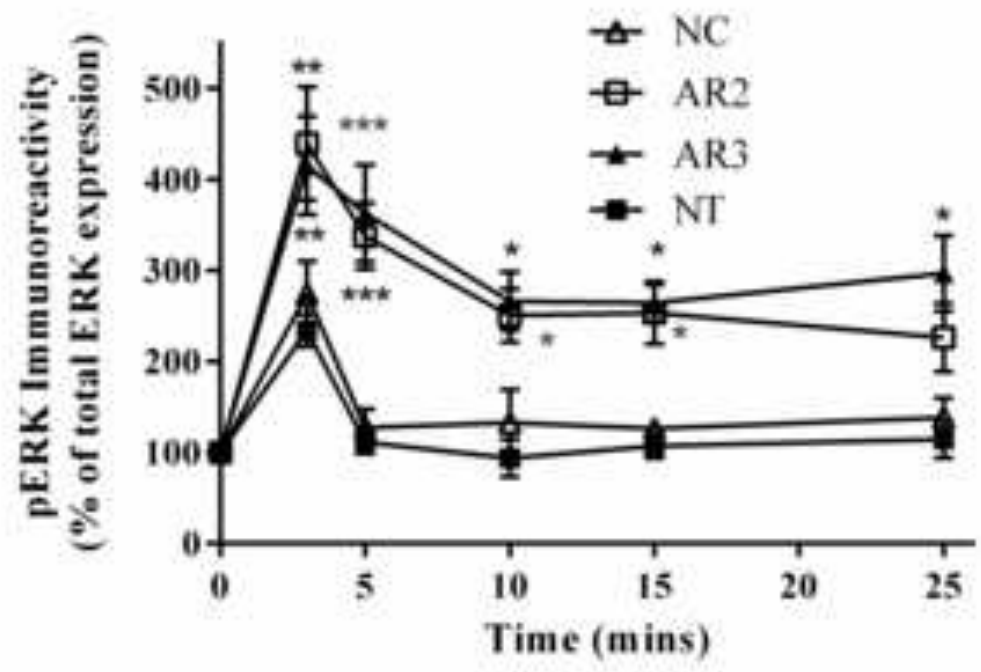




\section{Figure}

Click here to download high resolution image

\section{Figure 6}
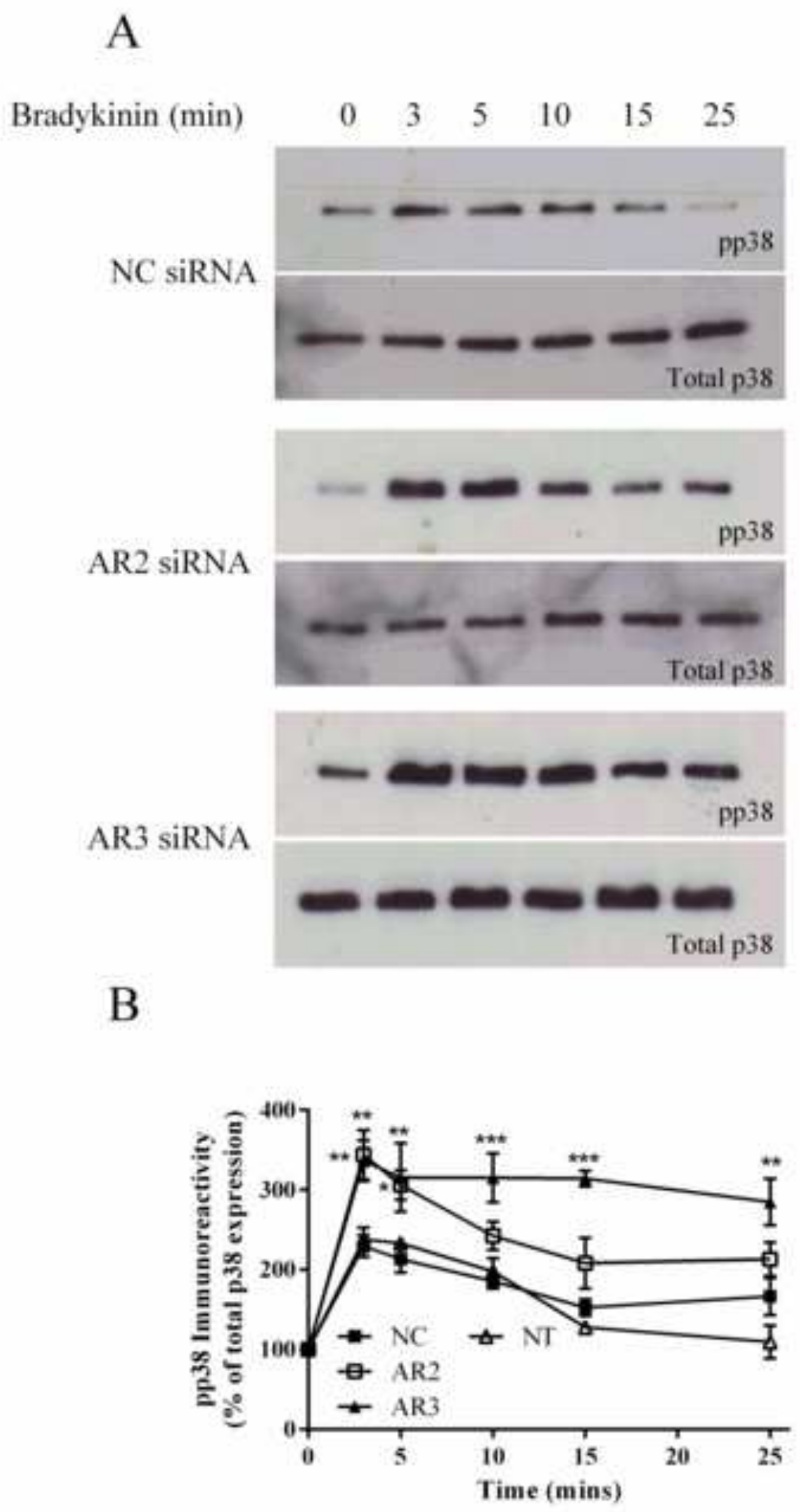
Figure
Click here to download high resolution image

\section{Figure 8}

A

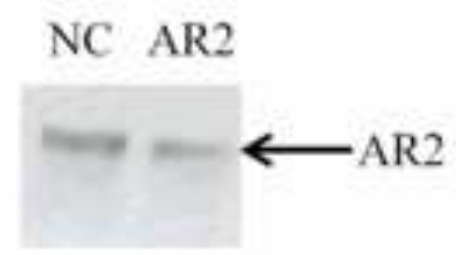

NC AR3
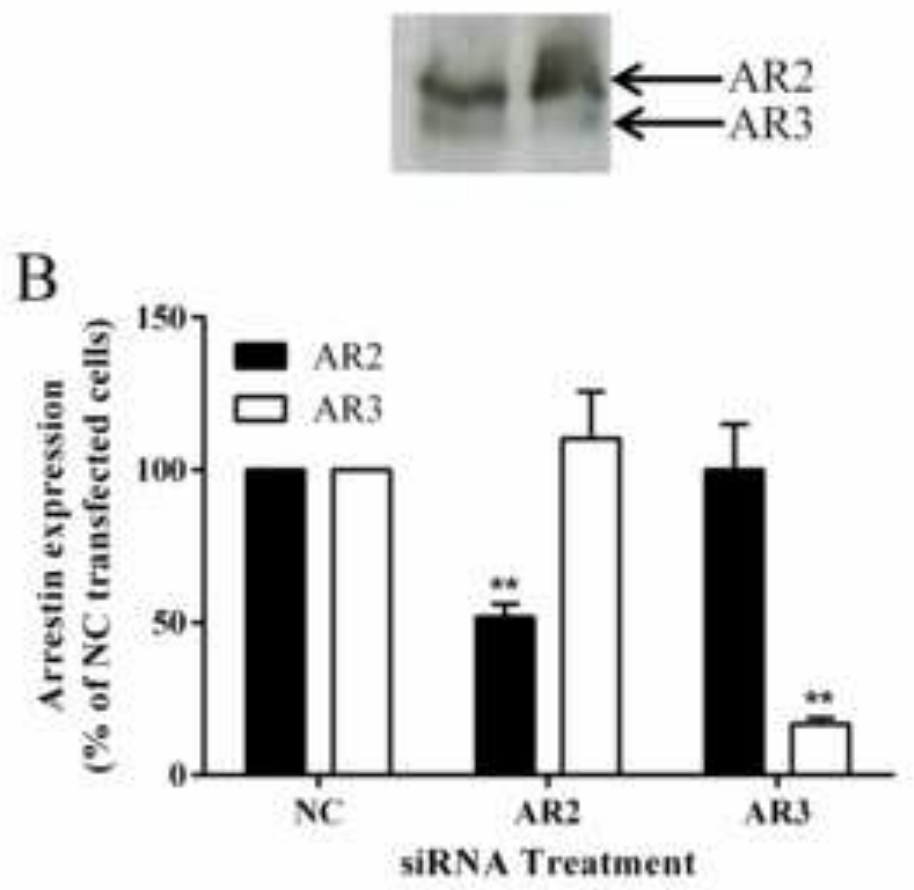

C

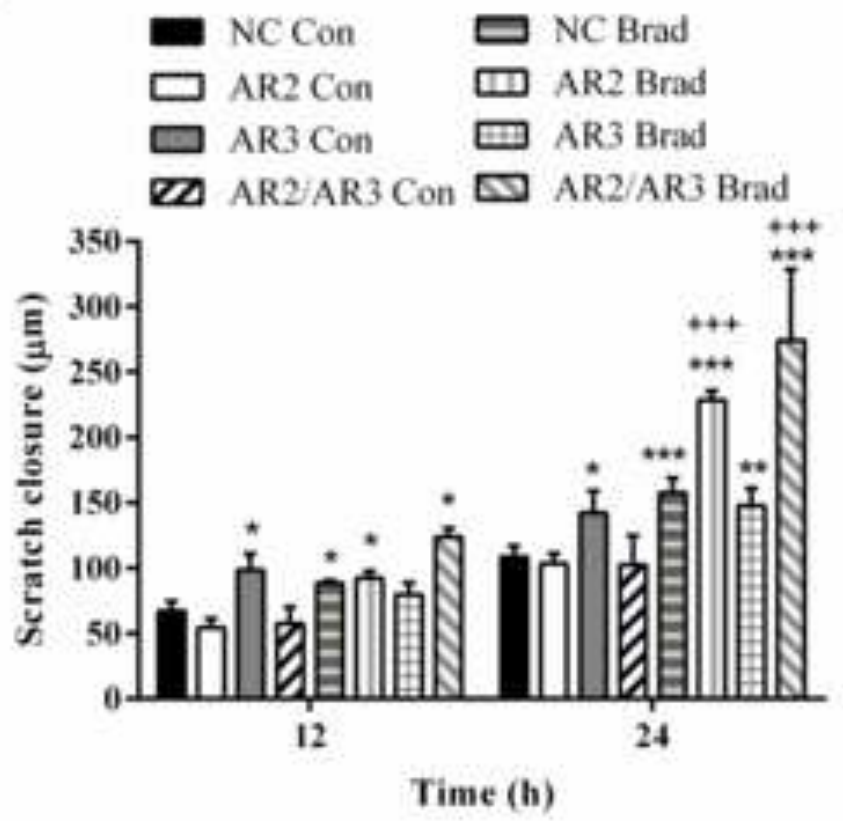




\section{Figure 7}

A

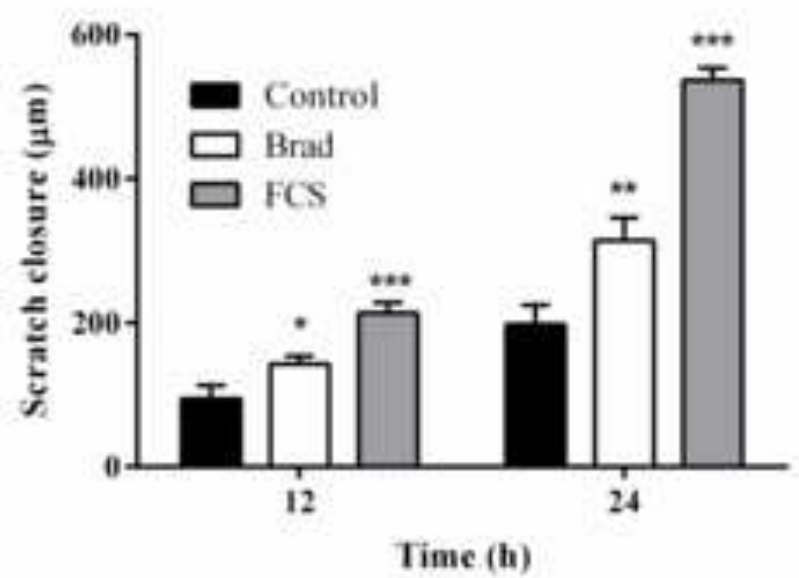

C

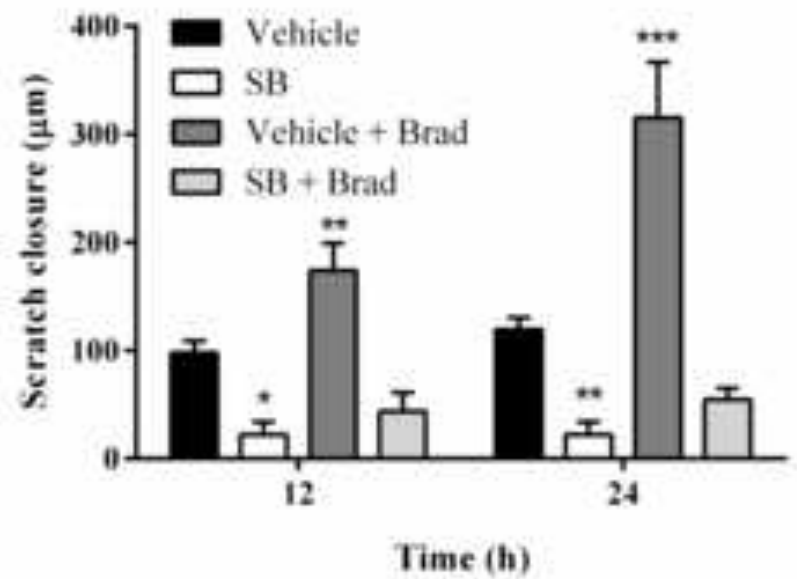

B

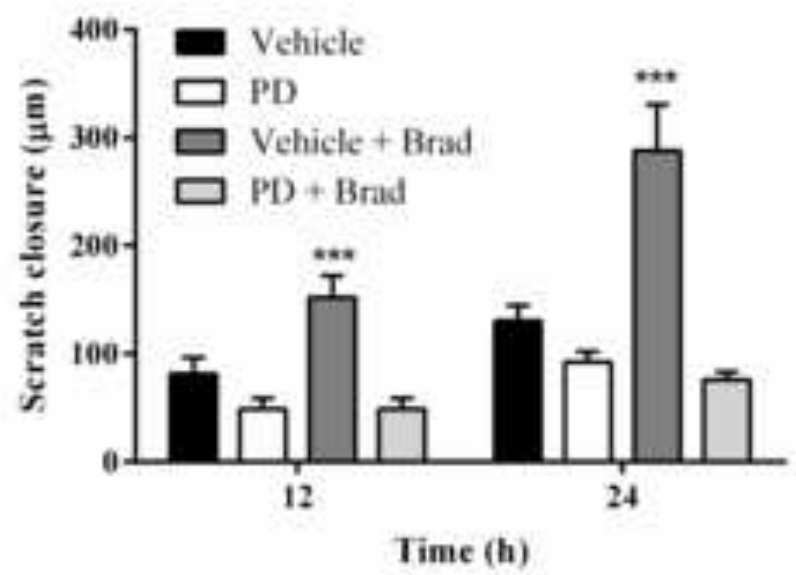

D

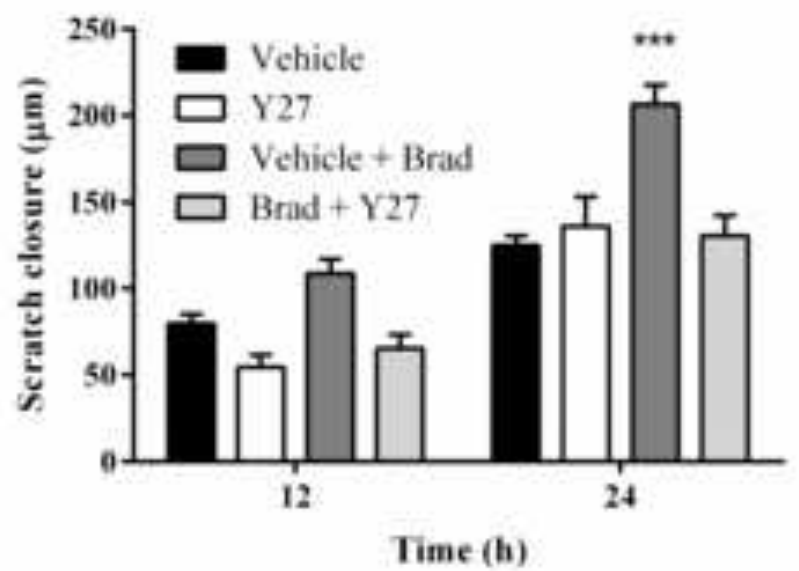


Supplementary Material
Click here to download Supplementary Material: SRFig1.tif

Supplementary Material
Click here to download Supplementary Material: SRFig1.tif 
Supplementary Material
Click here to download Supplementary Material: SRFig2.tif

Supplementary Material
Click here to download Supplementary Material: SRFig2.tif 
Supplementary Material
Click here to download Supplementary Material: SRFig3.tif

Supplementary Material
Click here to download Supplementary Material: SRFig3.tif 
Supplementary Material
Click here to download Supplementary Material: SRFig4.tif

Supplementary Material
Click here to download Supplementary Material: SRFig4.tif 